Accepted manuscript:

\title{
Metal cycling in Mesoproterozoic microbial habitats: Insights from trace elements and stable Cd isotopes in stromatolites
}

by

Sebastian Viehmann ${ }^{1}$, Simon V. Hohl ${ }^{2 *}$, Dennis Kraemer ${ }^{3}$, Michael Bau ${ }^{3}$, Detlef H.G. Walde ,Stephen J. G. Galer ${ }^{5}$, Shao-Yong Jiang ${ }^{6}$, Patrick Meister ${ }^{1}$

${ }^{1}$ University of Vienna, Department of Geodynamics and Sedimentology, Althanstr. 14, 1090 Wien, Austria

${ }^{2}$ Nanjing University, Department of Earth Sciences, Xianlin Ave. 168, 21000 Qixia District, Nanjing, P.R. China

${ }^{3}$ Jacobs University Bremen, Department of Physics and Earth Sciences, Campus Ring 1, 28759 Bremen, Germany

${ }^{4}$ Universidade de Brasília, Instituto de Geociências, Campus Universitário Darcy Ribeiro, 15 CEP 70910-900 Brasília, DF, Brazil

${ }^{5}$ Max Planck Institute for Chemistry, Climate Geochemistry Department, Hahn-Meitner-Weg 1, 55128 Mainz, Germany

${ }^{6}$ China University of Geosciences, State Key Laboratory of Geological Processes and Mineral Resources, Faculty of Earth Resources, Wuhan, P.R. China

https://doi.org/10.1016/j.gr.2018.10.014

Received 14 May 2018; Received in revised form 2 October 2018; Accepted 7 October 2018 Available online 12 December 2018 (Embargo: 24 months)

This manuscript has an agreement with CC-BY-NC-ND license (https://creativecommons.org/licenses/by-nc-nd/4.0/deed.de). 


\section{Metal cycling in Mesoproterozoic microbial habitats: Insights from trace} elements and stable $\mathrm{Cd}$ isotopes in stromatolites

Sebastian Viehmann ${ }^{1}$, Simon V. Hohl ${ }^{\star}$, Dennis Kraemer ${ }^{3}$, Michael Bau ${ }^{3}$, Detlef H.G. Walde ${ }^{4}$, Stephen J. G. Galer ${ }^{5}$, Shao-Yong Jiang ${ }^{6}$, Patrick Meister ${ }^{1}$

${ }^{1}$ University of Vienna, Department of Geodynamics and Sedimentology, Althanstr. 14, 1090 Wien, Austria

${ }^{2}$ Nanjing University, Department of Earth Sciences, Xianlin Ave. 168, 21000 Qixia District, Nanjing, P.R. China

${ }^{3}$ Jacobs University Bremen, Department of Physics and Earth Sciences, Campus Ring 1, 28759 Bremen, Germany

${ }^{4}$ Universidade de Brasília, Instituto de Geociências, Campus Universitário Darcy Ribeiro, CEP 70910-900 Brasília, DF, Brazil

${ }^{5}$ Max Planck Institute for Chemistry, Climate Geochemistry Department, Hahn-Meitner-Weg 1, 55128 Mainz, Germany

${ }^{6}$ China University of Geosciences, State Key Laboratory of Geological Processes and Mineral Resources, Faculty of Earth Resources, Wuhan, P.R. China

${ }^{*}$ corresponding author: Simon V. Hohl

Tel. +8613057563278

s.hohl@nju.edu.cn

Revised version, Gondwana Research

August 2018 


\section{Abstract}

Reconstructing the environmental conditions that supported early life on Earth relies on well-preserved geochemical archives in the rock record. However, many geochemical tracers either lack specificity or they are affected by post-depositional alteration. We present a data set of major and trace element abundances and $\mathrm{Cd}$ isotope compositions of dome-shaped and conophyton-type stromatolites of the Late Mesoproterozoic Paranoá Group (Brazil), showing distinct values with unprecedented resolution at the lamina scale.

The studied stromatolites consist of dolomite with a high purity and a negligible content of immobile elements (e.g., < $0.66 \mathrm{ppm} \mathrm{Zr}$ ), indicating that elemental compositions are not influenced by detrital contamination. Even though the carbonates have experienced different extent of recrystallization, the measured elemental and isotopic compositions do not correlate with fluid mobile elements. The stromatolites thus represent prime archives for geochemical proxies to reconstruct paleo-environmental conditions.

Two endmember compositions can be distinguished by multiple proxy analysis, reflecting the contrasting depositional environments of the two types of stromatolites: Shale-normalized rare earth elements including yttrium $\left(R E Y_{S N}\right)$ patterns of domal stromatolites show a light $\mathrm{REY}_{\mathrm{SN}}(\mathrm{LREY})$ enrichment $\left(\mathrm{Yb}_{\mathrm{SN}} / \mathrm{Pr}_{\mathrm{SN}}<0.84\right)$, slightly super-chondritic $\mathrm{Y} / \mathrm{Ho}$ ratios (33.6 39.3) and unfractionated $\mathrm{Cd}$ isotopes relative to upper continental crust. This indicates that the stromatolites formed in a shallow-water environment that was episodically influenced by seawater. Their REY and Cd compositions are dominated by dissolved elements that were delivered via weathering and erosion processes from the ambient continent.

In contrast, REY $Y_{S N}$ patterns of the conophyta are parallel those of modern seawater with an $L R E Y_{S N}$ depletion relative to $H R E Y_{S N}\left(Y_{S N} / P_{S N}=2.1\right.$ to 3.9), positive $\mathrm{Gd}_{S N}$ anomalies (1.1 to 1.4) and strong super-chondritic Y/Ho ratios (37.9 to 46.2), suggesting a microbial habitat that was dominated by seawater. $\mathrm{Cd}$ isotopes correlate negatively with $\mathrm{Cd}$ and $\mathrm{U}$, but positively with $\mathrm{Mn}$ and $\mathrm{Ce}$ concentrations, reflecting authigenic carbonate formation at different depths within a redox gradient of the ancient microbial mat. $\varepsilon^{112 / 110} C \mathrm{~d}_{\text {dol }}$ values increase from -3.52 at the mat surface to +3.46 in the interior of the mat, due to the effect of kinetic fractionation during Cd-uptake, e.g. by adsorption onto organic matter or by precipitation of sulfides, in addition to incorporation into carbonate minerals. Hence, our multi-proxy approach including $\mathrm{Cd}$ isotopes bears a high potential to shed light on environmental conditions in ancient microbial habitats and the activity of microbial life on Early Earth.

Keywords: Stromatolite, Precambrian, REY; Cd isotopes; carbonate formation; early life 


\section{Introduction}

The search for earliest life on Earth and the reconstruction of the physico-chemical 70 conditions under which a putative last universal common ancestor (LUCA) or other early life forms thrived has been a major topic of research during the past two decades (e.g., Martin and Russell, 2007; Allwood et al., 2010; Nutman et al., 2016; Weiss et al., 2016). Laboratory

experiments and DNA-based computer models were conducted to reconstruct the metabolic pathways of LUCA and the environment of the origin of life, which may reach back to Hadean times (e.g., Martin and Russell, 2007; Weiss et al., 2016). Stromatolitic carbonates are considered prime geochemical archives of microbial habitats throughout Earth's history (e.g., Webb \& Kamber 2000; Kamber et al., 2004; Bolhar \& van Kranendonk, 2007; Allwood et al., 2010; Webb \& Kamber, 2010; Kamber et al., 2014; Nutman et al., 2016; Schier et al., 2018). Stromatolites are interpreted as "organo-sedimentary structures formed by the incidental induction of mineral precipitation within or on microbial biofilms with, or without, trapping and binding of ambient sediments" (Webb \& Kamber 2010). They first appear in 3.5 Ga old sediments of the Pilbara Craton, Western Australia (e.g., Allwood et al., 2010) or perhaps already in $\sim 3.7 \mathrm{Ga}$ old laminated carbonates in the Isua Greenstone Belt, Greenland (Nutman et al., 2016), and they are found throughout most parts of the Precambrian record. While banded iron formations (BIF) represent deep-water depositional settings (e.g., Bau \& Dulski, 1996; Viehmann et al., 2015, 2016), stromatolites are generally considered to have formed within the photic zone in shallow-water environments (e.g., Webb \& Kamber, 2000; Kah et al., 2009; Allwood et al., 2010). Rare earth element and yttrium (REY) geochemistry of stromatolites was extensively used in the past to provide insight on different environmental parameters, such as relative water depth, redox conditions of the hydro- and atmosphere or the impact of high temperature hydrothermal fluids on the geochemical composition of ancient seawater (Kamber et al., 2014, and references therein). Hence, stromatolites are invaluable geochemical archives that may hold the key to our understanding of physico- 
chemical conditions, under which early life thrived and evolved, and of how these conditions were influenced by the emerging life.

Cadmium isotopes are a promising novel proxy for investigating biogeochemical cycling in ancient marine environments (e.g. Georgiev et al., 2015, John et al., 2016, Hohl et al., 2017), because dissolved Cd mimics concentration patterns of nutrient elements, such as $\mathrm{P}$ and potentially $\mathrm{Zn}$ in the modern ocean, i.e. it is consumed during primary production and released during degradation of biomass (Boyle et al., 1976, Middag et al., 2018). As a result, Cd isotopes in the modern ocean have been shown to fractionate upon uptake into biomass during primary production (Abouchami et al., 2014 and references therein). Results from recent studies on $\mathrm{Cd}$ isotopes in modern and ancient marine sediments bear the potential for recording changes in marine productivity in the surface water through Earth's history (Georgiev et al., 2015; John et al., 2016; Hohl et al., 2017).

We hypothesize, based on the observations from the open ocean mentioned above, that Cd-isotopes may provide a potential tracer for biomass production in benthic phototrophic microbial communities. Because light $\mathrm{Cd}$ isotopes are preferentially taken up by phototrophic organisms, the adjacent fluid would be expected to become enriched in heavy Cd isotopes. Hence, if phototrophic organisms thrived in ancient microbial mats, stromatolitic carbonates should show the same isotopic trend. Biogeochemical conditions and cycling of elements in stromatolites may fundamentally differ from pelagic primary production, and numerous effects could alter the pathways through which $\mathrm{Cd}$ is sequestrated into the solid 114 phase. For example, Cd may adsorb onto organic matter under anoxic conditions. Cadmium 115 may also form insoluble precipitates as sulfides. However, Cd isotopes could have a high 116 potential to be trapped in authigenic carbonate forming during microbial mat during 117 lithification. The Cd isotope compositions preserved in the authigenic carbonates could be 118 indicative of the extent of fractionation that occurred within the mat and, thus, provide insight 119 into biogeochemical processes occurring within the microbial mat while becoming lithified. In 120 the oldest carbonates so far analyzed, non-stromatolitic lime and dolostones from the 121 Ediacaran, $\varepsilon^{112 / 110} \mathrm{Cd}$ and $\delta^{13} \mathrm{C}$ values show a positive correlation, as it would be expected in 
122 bio-productive environments at the verge of multicellular life (Hohl et al., 2017). However, if 123 Cd isotopes show a similar trend in stromatolites from various locations that formed in 124 different depositional settings and show different morphologies is not known yet.

125 Our study presents a first attempt to differentiate $\mathrm{Cd}$ isotopes at high spatial 126 resolution in fossil stromatolites as part of a multi-proxy approach and in combination with a 127 detailed petrographic analysis. The analyzed stromatolites are from the Late 128 Mesoproterozoic Paranoá Group, Brazil. In order to decipher the influence of the depositional 129 environment on the geochemistry of the stromatolitic carbonates, two different morphological 130 types were sampled at two different locations, São Gabriel and Fazenda Funil, where the 131 sedimentary facies indicates different depositional conditions (Fairchild et al., 1996). Carbon 132 and oxygen isotopes in combination with major/trace element signatures were analyzed to 133 evaluate the impact of detrital contamination and post-depositional alteration of the 134 geochemical inventory of individual stromatolite samples. REY systematics of domal and conophyton-type stromatolites were measured to reconstruct the local physico-chemical stable $\mathrm{Cd}$ isotope data from these stromatolites, which are the oldest so-far analyzed carbonates for this proxy to better understand $\mathrm{Cd}$ fractionation processes in ancient microbial habitats. Based upon our results, Cd isotopes in stromatolitic carbonates may be established as a tracer for (bio)geochemical element cycling in ancient microbial mats in future research.

\section{Geological overview and sample description}

\subsection{Geological overview}

The Brasilia Belt contains Meso- to Neoproterozoic sedimentary units that were deposited on a passive continental margin of the Congo - Sao Francisco Craton as well as younger Neoproterozoic igneous-sedimentary rocks that formed during the Brasiliano-PanAfrican cycle (e.g., Pimentel and Fuck, 1992; Pimentel et al., 2011, Fig. 1a). The Paranoá Group is part of the Brasília Belt, and recent studies suggest a late Mesoproterozoic to earliest Neoproterozoic depositional age based on $\mathrm{Sr}-\mathrm{C}$ isotope data (Alvarenga et al., 
150 2014), while another study limits the Paranoá Group depositional age between $1.54 \mathrm{Ga}$, 151 based on $\mathrm{U}-\mathrm{Pb}$ dating of detrital zircons, and $1.04 \mathrm{Ga}$, based on $\mathrm{Lu}-\mathrm{Hf}$ dating of diagenetic 152 xenotime (Pimentel et al., 2011).

153 The mixed authigenic and siliciclastic sediments of the Late Mesoproterozoic to Early 154 Neoproterozoic Paranoá Group crop out in Middle East Brazil in the state Goiás close to the 155 
Conical stromatolites of the type Conophyton metulum Kirichenko of the uppermost 178 stratigraphic interval of the Paranoá Group were sampled at the Fazenda Funil location (Fig. 179 1a). Individual micritic conophyta may reach up to $4 \mathrm{~m}$ in height and $80 \mathrm{~cm}$ in width (Fig. 2b, 180 c., Fairchild et al., 1996) and are suggested to have been deposited in the photic zone during 181 a sea level rise on an open platform at a water depth of less than $20 \mathrm{~m}$ (e.g., Campos et al., 182 2012; Alvarenga et al., 2014). Macro-laminae at Fazenda Funil are between 0.5 and $3 \mathrm{~cm}$ 183 thick.

\section{Analytical Methods}

Micro-drill cores with a diameter of $400 \mu \mathrm{m}$ were drilled from single stromatolite macro-laminae, each consisting of several micro-laminae, using a Proxxon bench drill press TBM 115 at the Jacobs University at Bremen. The material was crushed in an agate mortar and pestle to a homogenous powder for trace and major element analyses. 100 to $200 \mathrm{mg}$ sample powder and the certified reference materials JDo-1 (Permian dolomite) and JLs-1 (Triassic limestone) were dissolved with $10 \mathrm{ml}$ of $5 \mathrm{~N} \mathrm{HNO}_{3}$ for a few minutes at $70^{\circ} \mathrm{C}$ until the chemical reaction stopped. The solutions were subsequently cooled down and filtered through a $0.2 \mu \mathrm{m}$ filter. The clear solutions were dried down and dissolved in $0.5 \mathrm{~N} \mathrm{HNO}_{3}+<$ 0.01 N HF for analysis with a Perkin Elmer Elan DRC-e quadrupol ICP-MS and Spectro Ciros Vision ICP-OES. In parallel, six samples of $200 \mathrm{mg}$ weight, micro-drilled from the stromatolites of the São Gabriel and Fazenda Funil locations, were dissolved with a concentrated $\mathrm{HNO}_{3}-\mathrm{HCl}-\mathrm{HF}$ mixture $(3: 1: 1)$ in a high pressure - high temperature digestion for $24 \mathrm{~h}$, following the protocol described by Viehmann et al. (2016) to monitor the impact of silicates and oxides on the trace element contents of the stromatolites.

Additional carbonate material from similar drill-holes, i.e. similar stromatolitic laminae, was sampled for $\mathrm{C}$ and $\mathrm{O}$ isotope analysis using a Silfradent driller with a diamond-bearing drill-bit. Approximately $100 \mu \mathrm{g}$ of carbonate powder was treated with $\sim 104 \%$ phosphoric acid at $70^{\circ} \mathrm{C}$ using a Gasbench II connected to a ThermoFisher Scientific MAT-253 massspectrometer at the State Key Laboratory for Mineral Deposits Research at Nanjing 
University, applying a similar method as described in Breitenbach and Bernasconi (2011). Isotopic compositions of $\mathrm{C}$ and $\mathrm{O}$ were determined in the liberated gas. The isotope ratio measurements were calibrated to the Vienna-PeeDee Belemnite (V-PDB) standard, using the in-house carbonate reference material GBW04405. (for further information see electronic supplement).

Stable Cd isotope analyses were performed on aliquots of the sample powders drilled for $\mathrm{C}$ and $\mathrm{O}$ isotope analysis. $500 \mathrm{mg}$ of sample powder was treated in pre-cleaned $50 \mathrm{~mL}$ centrifuge tubes with $50 \mathrm{~mL}$ of $1 \mathrm{~N}$ acetic acid $(\mathrm{pH}=5)$. The solutions were continuously rotated overnight at room temperature in a vial rotation device. Aliquots of the leachates, roughly containing $\sim 25 \mathrm{ng} \mathrm{Cd}$, were spiked with optimal amounts of ${ }^{106} \mathrm{Cd}-{ }^{108} \mathrm{Cd}$ double-spike solution, as described in Schmitt et al. (2009a). To separate the Cd from matrix elements, the solutions were passed through BioRad Polyprep columns filled with $200 \mu \mathrm{L}$ of BioRad AG1X8 anion-exchange resin (100-200 mesh). The resin was first washed with $2 \mathrm{~mL} 0.5 \mathrm{~N} \mathrm{HNO}_{3}$ and then equilibrated with $0.5 \mathrm{~N} \mathrm{HBr}$ before loading the samples. The remaining $\mathrm{Cd}$ on the column walls was washed into the resin by multiple additions of $0.1 \mathrm{~mL} 0.5 \mathrm{~N} \mathrm{HBr}$, followed by five steps of $1 \mathrm{~mL} 1 \mathrm{~N} \mathrm{HCl}$ to remove the bromide from the column and to elute the matrix elements. The Cd-fraction was then eluted with four times $1 \mathrm{~mL} 0.25 \mathrm{~N} \mathrm{HNO}_{3} .200 \mu \mathrm{L}$ of concentrated $\mathrm{HBr}$ was added to the eluent to create a final concentration of $0.5 \mathrm{~N} \mathrm{HBr}$; the solution was subsequently passed through the column for a second time to ensure complete purification (see Schmitt et al., 2009a). To remove organic remnants such as resin beads, the final solution was dried down and treated with three drops of $\mathrm{H}_{2} \mathrm{O}_{2}$ before dissolution in concentrated $\mathrm{HNO}_{3}$. Throughout the digestion and purification of the samples only ultrapure acids (Baseline grade, Seastar Chemicals) were used. The sample solutions containing approximately $25 \mathrm{ng} \mathrm{Cd}$ were loaded onto single Re filaments using a Teflon micro-tube syringe; the filaments were covered with $1 \mu \mathrm{L}$ silica gel-phosphoric acid activator. Cadmium isotope compositions were measured on a Triton (ThermoFisher) Thermal Ionization Mass Spectrometer (TIMS) at the Max Planck Institute for Chemistry in Mainz operating in static multi-collection mode with filament heating at about $\sim 1150^{\circ} \mathrm{C}$. Data were corrected for the 
natural and instrumental mass-dependent isotope fractionation using the double-spike algorithm, assuming an exponential fractionation law; the statistical uncertainties are based on reducing each measurement cycle (8 seconds) during the run. The double spike was originally calibrated against an unspiked in-house JMC Cd Plasma solution (Lot: 15922032) with ${ }^{110} \mathrm{Cd} /{ }^{112} \mathrm{Cd}=0.520089$ (Rosman et al., 1980). All $\mathrm{Cd}$ isotope compositions are expressed as $\varepsilon^{112 / 110} \mathrm{Cd}$ dol, which are deviations of ${ }^{112} \mathrm{Cd} /{ }^{110} \mathrm{Cd}$ in parts per 10.000 from the reference material NIST SRM 3108 (Lot: 130116) (Abouchami et al., 2012; Table 3). The long-term external reproducibility of $\varepsilon^{112 / 110} \mathrm{Cd}$ at the Max-Planck Institute for Chemistry is $\pm 0.16 \varepsilon$ units at the $2 \sigma$ level ( 2 SD). Two replicates of stromatolite acetic acid-leachates reproduce in the order of $0.35 \pm 0.4$ and $0.48 \pm 0.4 \varepsilon^{112 / 110} \mathrm{Cd}$ units, respectively. The overall procedural blank on acetic acid-leachates in this study is $48 \mathrm{pg}$. We obtained $\mathrm{Cd}$ concentrations using the isotope dilution method applied to the bias-corrected ${ }^{106} \mathrm{Cd} /{ }^{112} \mathrm{Cd}$ ratios. The analytical uncertainties of the $\mathrm{Cd}$ concentrations are usually less than $0.1 \%$ (2 RSD).

\section{Results}

\subsection{Major and trace elements}

Major and trace element data of nitric acid-leachates of the Fazenda Funil and São Gabriel stromatolites and the certified reference materials JDo-1 and JLs-1 are listed in Tables 1 and 2. Major element concentrations do not significantly differ between carbonates from the two locations. Stromatolites from São Gabriel yield 28.1 to 29.5 wt\% CaO and 20.2 to $21.0 \mathrm{wt} \% \mathrm{MgO}$. Conophyta of the Fazenda Funil fall into the same range in the $\mathrm{CaO}(28.6$ to 29.7 wt $\%$ ) and $\mathrm{MgO}$ content (19.9 to $21.3 \mathrm{wt} \%) . \mathrm{Al}_{2} \mathrm{O}_{3}$ contents $(<0.2 \mathrm{wt} \%)$ of both the Fazenda Funil and São Gabriel carbonate are homogenous but very low, and they overlap with the $\mathrm{Al}_{2} \mathrm{O}_{3}$ content of the dolomite standard JDo-1 (Tables 1 and 2). $\mathrm{FeO}$ and $\mathrm{MnO}$ are slightly enriched in Fazenda Funil carbonates (0.4 to 0.9 wt $\%$ and 0.05 to 0.06 wt\%, resp.) relative to $\sim 0.1 \mathrm{wt} \% \mathrm{FeO}$ and $\sim 0.01 \mathrm{wt} \% \mathrm{MnO}$ in São Gabriel stromatolites. 
Trace element concentrations are generally lower in the São Gabriel stromatolites

relative to those of the Fazenda Funil (Tables 1 \& 2; Fig. 3). In all analyzed carbonates the nitric acid-leachable fraction shows low but homogenous concentrations of immobile elements that are commonly related to detrital aluminosilicates. Consistent with very low $\mathrm{Al}$ concentrations, $\mathrm{Zr}$ concentrations are between 0.39 and $0.66 \mathrm{ppm}$, and $\mathrm{Rb}$ concentrations are between 0.076 and $0.25 \mathrm{ppm}$. $\Sigma$ REY concentrations range from 3.67 to $5.85 \mathrm{ppm}$ at São Gabriel and from $9.15 \mathrm{ppm}$ to $16.1 \mathrm{ppm}$ at the Fazenda Funil. In the fully digested samples (high-pressure and high-temperature digestion with a conc. $\mathrm{HF}-\mathrm{HNO}_{3}-\mathrm{HCL}$ mixture), $\Sigma \mathrm{REY}$ concentrations of Fazenda Funil (12.3 to 12.8 ppm) and São Gabriel (3.13 to 3.97 ppm) stromatolite samples (Tables 1 \& 2) fall into a similar range as in the nitric acid-leachates, but the concentrations of immobile elements are slightly elevated (Tables 1 \& 2, Figs. 3 \& 4). Overall REY concentrations of authigenic stromatolitic carbonates are up to $25 \%$ higher than the carbonate infill between the stromatolites in both nitric acid-leachates and $\mathrm{HF}-\mathrm{HNO}_{3}-\mathrm{HCl}$ digestions (Table 1).

São Gabriel carbonates are HREY ${ }_{S N}$ depleted with $\mathrm{Yb}_{\mathrm{SN}} / \mathrm{Pr}_{\mathrm{SN}}$ ratios between 0.72 and 0.84 , and they show positive $\mathrm{Y}_{\mathrm{SN}}$ and $\mathrm{Gd}_{\mathrm{SN}}$ anomalies with $\mathrm{Y} / \mathrm{Ho}$ ratios between 33.6 and 39.3 and $\mathrm{Gd}_{\mathrm{SN}} / \mathrm{Gd}_{\mathrm{SN}}{ }^{*}$ ratios between 1.1 and 1.3 (Table 1, Fig. 4, for equations, see electronic supplement). If normalized to locally abundant plutonic country rocks from the São Francisco Craton (Barbosa et al., 2008), positive $\mathrm{Y}$ and $\mathrm{Gd}$ anomalies (Gd/Gd* ratios between 0.93 to 1.11) are persistent and the REY patterns are HREY enriched relative to the LREY (Yb/Nd > 8.1 Fig. 4). In contrast, Fazenda Funil carbonates show typical seawater-like HREY ${ }_{S N}$ enrichment with $\mathrm{Yb}_{\mathrm{SN}} / \mathrm{Pr}_{\mathrm{SN}}$ ratios between 2.1 and 3.9, super-chondritic $\mathrm{Y} / \mathrm{Ho}$ ratios between 37.9 and 46.2 , and positive $\mathrm{Gd}_{\mathrm{SN}}$ anomalies with $\mathrm{Gd}_{\mathrm{SN}} / \mathrm{Gd}_{\mathrm{SN}}{ }^{*}$ ratios between 1.1 and 1.4 (Table 2, Fig. 4). Insignificant to slightly positive $\mathrm{Eu}_{\mathrm{SN}}$ anomalies are observed in stromatolites of both locations $\left(\mathrm{Eu}_{\mathrm{SN}} / \mathrm{Eu}_{\mathrm{SN}}{ }^{*}\right.$ ratios between 1.0 and 1.2). However, in chondrite-normalized patterns, $\mathrm{Eu}_{\mathrm{CN}} / \mathrm{Eu}_{\mathrm{CN}}{ }^{*}$ ratios do not exceed 0.7 , indicating that the positive $\mathrm{Eu}_{\mathrm{SN}}$ anomalies are an artifact of shale-normalization and do not provide true geochemical information. $\mathrm{Ce}_{\mathrm{SN}} / \mathrm{Ce}_{\mathrm{SN}^{*}}{ }^{*}$ ratios of both locations range between 0.95 and 0.75 . 


\subsection{Stable carbon, oxygen and cadmium isotopes}

$\delta^{13} \mathrm{C}_{\text {dol }}$ values of São Gabriel carbonates are positive with low variation $(+1.9 \pm 0.1$ to $+2.1 \pm 0.1)$ while those at Fazenda Funil are generally negative with higher variation $\left(\delta^{13} C_{d o l}=\right.$ $-1.3 \pm 0.1$ and $-0.7 \pm 0.1$, Tables 1 and 2 ). $\delta^{18} \mathrm{O}_{\text {dol }}$ values also differ between the two locations with more negative values at São Gabriel $(-5.2 \pm 0.2$ to $-3.9 \pm 0.1)$ than at the Fazenda Funil ($3.9 \pm 0.1$ to $-2.7 \pm 0.1$; Tables 1 and 2 ).

Cadmium isotope compositions measured in acetic acid-leachates of stromatolitic carbonates from both locations and in the Jurassic calcite CAL-S (Yeghicheyan et al., 2003) are given in Table 3. Two values from São Gabriel stromatolites overlap within their analytical error $\left(\varepsilon^{112 / 110} C d_{d o l}\right.$ of $-0.58 \pm 0.3$ and $\left.-0.17 \pm 0.5\right)$, while Cd concentrations are 120 and $38 \mathrm{ng} / \mathrm{g}$, respectively. $\varepsilon^{112 / 110} \mathrm{Cd}_{\mathrm{dol}}$ values in ten samples from Fazenda Funil vary between $-3.52 \pm 0.5$ and $+3.46 \pm 1.8$. The lowest $\mathrm{Cd}$ concentrations (down to $5.7 \mathrm{ng} / \mathrm{g}$ ) coincide with the most positive $\varepsilon^{112 / 110} \mathrm{Cd}_{\text {dol }}$ values; high $\mathrm{Cd}$ concentrations (up to $24.9 \mathrm{ng} / \mathrm{g}$ ) are found in stromatolites showing the most negative $\varepsilon^{112 / 110} \mathrm{Cd}_{\mathrm{dol}}$ values.

While average $\varepsilon^{112 / 110} \mathrm{Cd} \mathrm{d}_{\text {calcite }}$ values obtained in two analyses of the Jurassic limestone reference material CAL-S $(+1.3)$ are in the same range as the positive $\varepsilon^{112 / 110} C d_{d o l}$ values of the Fazenda Funil carbonates, the Cd concentration in the reference material (322 $\mathrm{ng} / \mathrm{g}$ ) is much higher than in all our sampled Mesoproterozoic stromatolites. Cd isotope compositions in different stromatolites can be discerned as most samples show an analytical precision better than $0.5 \varepsilon$ units, except in three samples exceeding an uncertainty of $1 \varepsilon$ units due to extremely low Cd concentration (Table 3).

\section{Discussion}

\subsection{The impact of post-depositional alteration on the stromatolitic REY and Cd}

\section{budgets}

Ruling out potential post-depositional alteration effects is a prerequisite for the use of geochemical proxies in sediments to investigate the physico-chemical conditions in palaeo- 
environments. The impact of carbonate alteration on a geochemical proxy is commonly determined by the variation of fluid-mobile elements such as $\mathrm{Sr}, \mathrm{Ba}$ and stable $\mathrm{O}$ isotopes relative to the proxy of interest (e.g. Kamber et al., 2004; Nothdurft et al., 2004; Webb \& Kamber, 2010; Hohl et al., 2015; Schier et al., 2018). REY and Cd are not considered mobile during fluid-rock interactions, but diagenetic or metamorphic processes may, nevertheless, have altered their concentrations and isotopic composition. Under the assumption that any post-depositional process, that alters a proxy of interest, alters the concentrations of fluidmobile elements proportionally, we could use a linear correlation of the proxy to a fluid mobile element as an indicator of post-depositional alteration.

Negative $\delta^{18} \mathrm{O}_{\text {dol }}$ values in carbonates at São Gabriel may result from re-equilibration with pore-fluids at elevated temperatures during burial, but may also suggest a meteoric influence. In contrast, the values are largely unaltered at the Fazenda Funil location. At both locations, REY concentrations show no correlation with $\delta^{18} \mathrm{O}_{\text {dol }}\left(r^{2}=0.45\right.$, Fig. 3c) and $\mathrm{Sr}$ concentrations (Fig. 3 a, c), indicating that meteoric alteration or post-depositional fluid-rock interactions had negligible impact on the REY budget of the studied stromatolitic carbonates. $\varepsilon^{112 / 110} \mathrm{Cd}_{\mathrm{dol}}$ values and $\mathrm{Cd}$ concentrations in stromatolite leachates from the Late Mesoproterozoic Paranoá Group neither show correlations with fluid-mobile elements nor with $\delta^{18} \mathrm{O}_{\text {dol }}$ values (Fig. $3 \mathrm{~d}$, f; table 3). Although we do not know the original $\mathrm{Cd}$ concentration of the stromatolites at the time of formation, a correlation with the above mentioned proxies would commonly be expected within diagenetically altered carbonates. Such a pattern could also be accompanied by a preferential transport of light $\mathrm{Cd}$ isotopes into recrystallized dolomite or the interstitial space between carbonate minerals. However, $\varepsilon^{112 / 110} \mathrm{Cd}_{\mathrm{dol}}$ values do not correlate with fluid alteration proxies, such as $\mathrm{Sr}$ concentrations (Fig. 3d) or oxygen isotope compositions $\left(r^{2}=0.4\right.$; Fig. 3f). Furthermore, if Cd isotopes were fractionated during post-depositional alteration, recrystallization would be expected in Fazenda Funil stromatolites that show variable $\varepsilon^{112 / 110} \mathrm{Cd}_{\text {dol }}$ values. However, only the São Gabriel stromatolites show botryoidal cements overprinted by a dolomitic fabric, while stromatolites at Fazenda Funil essentially show an apparent pristine carbonate structure with 
344 alternations of dolomicrite and primary crystal fans with their crystallographic orientation 345 preserved (Fig. S1).

\subsection{The impact of detrital contamination on the stromatolitic REY and Cd budgets}

The reliability of the analyzed carbonates as archives for geochemical proxies to reconstruct the physico-chemical conditions in ancient environments and (bio)geochemical conditions within ancient microbial mats depends on the extent of detrital contamination during stromatolite formation or during acid-leaching of the sample material in the laboratory. Both sedimentation as well as trapping and binding of siliciclastic material in stromatolites are common, and even minute amounts of detrital contamination and leaching of these aluminosilicates may mask the pristine geochemical composition of the authigenic carbonate (e.g., Nothdurft et al., 2004; Webb \& Kamber, 2010; Schier et al., 2018). While concentrations of the immobile elements $\mathrm{Zr}$, $\mathrm{Rb}$ and $\mathrm{Hf}$ are slightly elevated in the $\mathrm{HF}-\mathrm{HNO}_{3}-$ $\mathrm{HCl}$ digested samples (open symbols in Figs. 3 \& 4) relative to the nitric acid-leachates, REY concentrations of both digestion methods lie in a similar range (Tables 1 \& 2, Fig. 3b) and show sub-parallel REYSN patterns (Fig. 4). This indicates that detrital aluminosilicates did not significantly contribute to the REY budget of the stromatolitic nitric acid-leachates. Negligible impact of detrital material is further corroborated by the lack of significant correlations between REY or Cd isotope compositions with immobile elemental concentrations, respectively (Fig. 3b, e). This is supported also by the absence of detrital minerals in the thin sections (Fig. S1) and XRD analyses (Fig. S2). Very low Rb concentrations in the samples of both the Fazenda Funil and São Gabriel locations additionally show that volcanic ash or pore-fluids that may have leached ambient clastic sediments did not significantly contribute to the geochemical composition of the fluid from which the authigenic carbonate was precipitated.

Furthermore, Cd concentrations and isotope compositions were calculated for a pure authigenic fraction based on the Al concentrations in the nitric acid-leachates. We followed an approach by Rodler et al. (2016) to correct for any detrital Cd input. The calculated 
372 authigenic $\mathrm{Cd}$ concentrations differ from the uncorrected (measured) data in the range from $3731.2 \%$ to $11.8 \%$ that corresponds to $0.2 \varepsilon^{112 / 110} \mathrm{Cd}$ units; one sample with a significantly lower 374 Cd concentration, however, shows a concentration difference of $24.8 \%$ and $0.34 \varepsilon^{112 / 110} \mathrm{Cd}$ units from the uncorrected (measured) data (Table 3, see electronic supplement for more information). However, Cd isotope compositions were obtained by acetic acid-leaching, while $377 \mathrm{Al}$ concentrations that were used for detritus correction were determined by $5 \mathrm{~N} \mathrm{HNO}_{3}$

\subsection{Reconstruction of the Paranoá group stromatolite depositional settings}

Conophyta from Fazenda Funil show typical seawater-like HREY $Y_{S N}$ over $L R E Y_{S N}$ enrichment and positive $\mathrm{Gd}_{\mathrm{SN}}$ and $\mathrm{Y}_{\mathrm{SN}}$ anomalies (Fig. 4a). The REY $\mathrm{SN}_{\mathrm{N}}$ patterns are, except for the redox-sensitive elements $\mathrm{Ce}$ and $\mathrm{Eu}$, sub-parallel to the pattern of modern seawater, which suggests that the depositional milieu at Fazenda Funil was under continuous influence 
of Mesoproterozoic seawater (summarized in Fig. 5). These findings are in agreement with 401 former studies (e.g. Campos et al., 2012; Alvarenga et al., 2014) that suggested a subtidal, deeper marine environment during a transgressive period. High-relief conical stromatolites as sampled at Fazenda Funil are interpreted to have grown in a subtidal setting, below the fair weather wave base (Kah et al., 2009, and references therein).

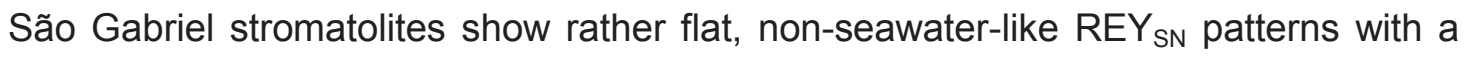
slight LREY $Y_{\mathrm{SN}}$ enrichment (Fig. 4b). Combined with systematically lower $\delta^{18} \mathrm{O}_{\text {dol }}$ values (Fig.

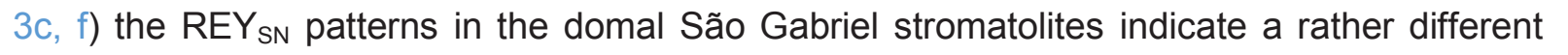
water chemistry than in the conophyta of Fazenda Funil. Yet, slightly positive $\mathrm{Y}_{\mathrm{SN}}$ and $\mathrm{Gd}_{\mathrm{SN}}$ anomalies typical for seawater indicate that the São Gabriel water also was saline or brackish, because even minute contributions of seawater may cause these anomalies in freshwater (e.g., Tepe and Bau, 2016). However, the slight enrichment of LREY $\mathrm{HREY}_{\mathrm{SN}}$ is more difficult to explain. The most plausible explanation, besides postdepositional fluid alteration, which was already ruled out, would be a shallow lagoon that was only episodically connected to seawater. The water chemistry in such an environment and its REY $Y_{S N}$ pattern should therefore be dominated by the pattern of weathered and eroded continental rocks of the hinterland (summarized in Fig. 5). Indeed, if normalized to Paleoproterozoic plutonic rocks of the São Francisco Craton (Barbosa et al., 2008) that yield the highest abundance of zircon ages within clastic sediments of the Paranoá Group (Matteini et al. 2012), the REY patterns of the São Gabriel stromatolites are parallel to the pattern of seawater (Fig. 4b). Hence, the stromatolitic habitat at São Gabriel was most likely comparable to that of the Late Archean Mushandike stromatolites (Zimbabwe) that were deposited in an environment variably restricted from the open ocean and dominated by dissolved REY from a weathered Tonalite-Trondhjemite-Granodiorite (TTG) complex (Kamber et al., 2004). Our geochemical reconstruction of the depositional environment of the domal stromatolites of São Gabriel is supported by sedimentological evidence of a sea level low stand (Fig. 1; Fairchild et al., 1996), which is consistent with their occurrence in the 
427 regressive interval of the ParanoGroup. The stromatolite morphology is representative for 428 supratidal to intertidal depositional environments (e.g., Kah et al., 2009).

\subsection{The potential of $\mathrm{Cd}$ isotopes to trace biogeochemical conditions in stromatolitic} carbonates

\subsubsection{Non-fractionated Cd isotopes in stromatolites from São Gabriel}

São Gabriel stromatolites show a homogenous $\mathrm{Cd}$ isotope distribution with 
$455 \quad \varepsilon^{112 / 110} \mathrm{Cd} d$ values between $-0.17 \pm 0.5$ and $-0.58 \pm 0.3$. The $\varepsilon^{112 / 110} \mathrm{Cd}$ values overlap within 1 the error with average loess $\left(\varepsilon^{112 / 110} \mathrm{Cd}\right.$ relative to NIST SRM $\left.3108=+0.04 \pm 0.31\right)$, i.e. the currently best available representative of the upper continental crust (Schmitt et al., 2009b). Furthermore, the $\varepsilon^{112 / 110} \mathrm{Cd}_{\mathrm{dol}}$ values at São Gabriel are close to the values measured in a shallow marine stromatolite from the Cambrian Bayan Gol Formation in the Altai Region of West Mongolia $\left(\varepsilon^{112 / 110} \mathrm{Cd}_{\mathrm{dol}}=+0.37,87.4 \mathrm{ng} / \mathrm{g}\right)$. The precipitation experiments by Horner et al. (2011) revealed no fractionation between calcite (or dolomite) and fluid in freshwater, while the fractionation in saline water (salinity $>35 \%$ ) shows a kinetic fractionation effect in the order of $\Delta \varepsilon^{112 / 110} \mathrm{Cd}_{\text {fluid-calcite }}$ of -2.27 . Furthermore, Lambelet et al. (2013) have shown that the budget of dissolved $\mathrm{Cd}$ and its isotopic composition in waters of deltaic environments is related to the freshwater/seawater ratio, i.e. $\varepsilon^{112 / 112} \mathrm{Cd}$ values and $\mathrm{Cd}$ concentrations increase with increasing salinity. Homogenous $\mathrm{Cd}$ isotope values and a lack of a negative correlation of $\varepsilon^{112 / 110} \mathrm{Cd}_{\mathrm{dol}}$ values with $\mathrm{Cd}$ concentrations in stromatolites imply that the dissolved $\mathrm{Cd}$ in the São Gabriel waters reflect the $\mathrm{Cd}$ isotope composition derived from continental weathering, probably as a result of higher freshwater input. This speaks against a significant microbial influence on the Cd budget trapped in the stromatolitic carbonates, although a microbial influence would be expected to play a role during authigenic carbonate precipitation from low salinity waters, encrusting the very surface of the stromatolites (cf. Birgel et al., 2015).

\subsubsection{Fractionated $\mathrm{Cd}$ isotopes in Fazenda Funil stromatolites}

In contrast to stromatolitic carbonates of the São Gabriel location, the Cd isotope compositions of the Fazenda Funil stromatolites show a high variability in $\varepsilon^{112 / 110} \mathrm{Cd}_{\mathrm{dol}}$ values between -3.52 and +3.46 . The $\varepsilon^{112 / 110} \mathrm{Cd}_{\mathrm{dol}}$ values show an inverse correlation with $\mathrm{Cd}$ and $\mathrm{U}$ concentrations $\left(r^{2}=0.85\right.$ and 0.9 ; Table 3; Fig. 6b, 7a) and a positive correlation with Mn concentrations and $\mathrm{Ce} / \mathrm{Ce}^{*} \mathrm{SN}$ ratios $\left(r^{2}=0.95\right.$ and 0.95 ; Fig. $\left.6 \mathrm{c}, \mathrm{d}\right)$. The linear correlation suggests mixing of two endmembers, representing carbonate formation in two different micro-environments within different microbial mat levels: 
Endmember I shows a negative $\varepsilon^{112 / 110} \mathrm{Cd}_{\mathrm{dol}}$ value $(-3.52)$, high $\mathrm{Cd}$ and $\mathrm{U}$

concentrations, low Mn concentrations and a negative Ce-anomaly (Fig. 6b-d, 7a). The negative $\mathrm{Ce}_{\mathrm{SN}}$ anomaly indicates rather oxidative conditions under which $\mathrm{Ce}$ and $\mathrm{Mn}$ are removed from the ambient fluid due to precipitation of Mn-(oxy)hydroxides. High $\mathrm{Cd}$ and $\mathrm{U}$ concentrations are probably the result of higher solubility of most redox sensitive elements (except $\mathrm{Mn}, \mathrm{Fe}$ ) under an elevated $\mathrm{pO}_{2}$ (e.g. Tribovillard et al., 2006), leading to a preferential incorporation of these elements into carbonates (Hohl et al., 2015).

Endmember II shows a positive $\varepsilon^{112 / 110} \mathrm{Cd}$ dol value $(+3.46)$ with low $\mathrm{Cd}$ and $\mathrm{U}$ concentrations but elevated $\mathrm{Mn}$ and Ce concentrations, i.e. a less negative $\mathrm{Ce}_{\mathrm{SN}}$ anomaly relative to endmember I (Fig. 6b-d, 7a). The elevated Mn concentration and the less negative $\mathrm{Ce}_{\mathrm{SN}}$ anomaly are consistent with Mn-reduction, releasing $\mathrm{Mn}(\mathrm{II})$ and $\mathrm{Ce}$ (among other elements adsorbed to $\mathrm{Mn}(\mathrm{oxy})$ hydroxides) into the fluid where they become available for incorporation into Mn-carbonates (Hohl et al., 2017). Low Cd and U concentrations are the result of low solubility of these elements under anoxic or even sulfidic conditions in the interior of the microbial mat/stromatolite (Tribovillard et al., 2006).

The linear correlation of $\mathrm{Cd}$ isotope values with concentrations of redox-sensitive elements may be interpreted as a result of diffusive mixing within a redox gradient. However, element-isotope ratio mixing generally creates hyperbolic but not the observed linear trends (Albarède, 1995). Furthermore, no correlation of $\varepsilon^{112 / 110} \mathrm{Cd}_{\mathrm{dol}}$ with $\delta^{13} \mathrm{C}_{\mathrm{dol}}$ exists (Fig. $6 \mathrm{a}$ ) in 502 carbonates from Fazenda Funil, which is in contrast to modern seawater (de Baar et al., 503 2017) and Ediacaran shallow water cap carbonates (Hohl et al., 2017). Such a correlation 504 would be expected during mixing processes of water masses from different zones, i.e. 505 upwelling at continental margins that provide a constant source of trace metals and $\mathrm{C}$ for 506 photosynthetic organisms in the surface waters. Modern phytoplankton is dependent on $\mathrm{CO}_{2}$ 507 in surface water and its enrichment in ${ }^{13} \mathrm{C}$ is widely accepted as an indicator for primary 508 productivity (e.g. Hollander et al., 1991).

509 One explanation for the decoupling of $\mathrm{Cd}$ and $\mathrm{C}$ isotopes in the Fazenda Funil 510 conophyta may be their very different chemical behavior under reducing conditions in a semi- 
511 closed biological system, as dissolved inorganic carbon would be released within the 512 stromatolite while $\mathrm{Cd}$ (and $\mathrm{U}$ ) would be bound into organic-rich sediments (Tribovillard et al., 513 2006) and/or authigenic sulfides (Guinoiseau et al., 2018). This would cause strong Cd 514 limitation under anoxic conditions within the microbial mat. Further research, however, is 515 needed to fully understand $\mathrm{Cd}$ isotopes as a tracer for biogeochemical Cd uptake in modern 516 and ancient environments.

\subsubsection{High-resolution snapshot of biogeochemical processes in Late Mesoproterozoic} microbial mats

Modern microbial mats such as those of the Lagoa Vermelha, a hypersaline lagoon near Rio de Janeiro (Brazil, Vasconcelos et al., 2006), are mainly composed of microbial extracellular polymeric substances (EPS), providing a diffusive framework in which a redox gradient is established, and the different redox zones are inhabited by different types of microorganisms. The microorganisms also influence the redox zones by their metabolism and may induce carbonate precipitation at the mat surface or in the interior of the mat. While oxygenic phototrophs reside under oxic conditions at the mat surface, anoxygenic phototrophs thrive under reducing conditions a few $\mathrm{mm}$ below the mat surface. Anoxygenic phototrophs may anaerobically oxidize reduced compounds such as sulfide, using energy from sunlight and the sulfide produced by sulfate reducing bacteria in the interior of the mat.

Comparing Late Mesoproterozoic Fazenda Funil stromatolites to modern microbial mats may help to interpret our observed isotope/element patterns (Fig. 5) and to develop a conceptual model for element uptake and isotope fractionation under anoxic, diffusion-limited conditions in a microbial mat. In this model, the $\mathrm{Cd}$ isotope composition of precipitated carbonates could be best described by a Rayleigh fractionation (Fig. 7b), in which the uptake of light $\mathrm{Cd}$ isotopes into biomass would lead to an ongoing depletion of the interstitial fluid in isotopically light $\mathrm{Cd}$. Due to the low solubility (or strong adsorption to organic matter) of $\mathrm{Cd}$ under anoxic conditions, Cd concentrations are very low, and the according Rayleigh effect is high (see trend in Fig. 7a). According to this model, carbonates forming at the microbial mat 
539 surface, represented by carbonate endmember I, directly trap the elemental composition of 540 oxic seawater with a negative Ce-anomaly and isotopically light $\mathrm{Cd}$. In contrast, carbonates 541 forming within the microbial mat, represented by endmember II, trap ions from reducing pore542 fluids enriched in $\mathrm{Ce}$ and $\mathrm{Mn}$, but depleted in $\mathrm{U}$ and $\mathrm{Cd}$ that are poorly soluble under 543 anoxic/sulfidic conditions. The Cd isotope composition in carbonates that were formed within the microbial mat, therefore, shows higher $\varepsilon^{112 / 110} \mathrm{Cd}_{\text {dol }}$ values corresponding to lower $\mathrm{Cd}$ and $\mathrm{U}$ concentrations as a result of continuous precipitation from $\mathrm{Cd}-\mathrm{U}$ depleted fluid within the anoxic and potentially sulfidic interior of the microbial mat.

The trend that the $\varepsilon^{112 / 110} \mathrm{Cd}_{\mathrm{sw}}$ values are highest when the $\mathrm{Cd}$ concentrations are lowest is in accordance with trends reported in the modern surface ocean (Fig. 7a; Abouchami et al., 2014; Xie et al., 2017; Middag et al., 2018). The widely accepted explanation for this inverse correlation is the preferential uptake of light $\mathrm{Cd}$ into biomass during primary production, leaving the remaining water $\mathrm{Cd}$ depleted and enriched in isotopically heavy Cd (Lacan et al., 2006). In turn, re-mineralization of sinking organic matter leads to an increase of the $\mathrm{Cd}$ concentrations and a decrease of $\varepsilon^{112 / 110} \mathrm{Cd}$ sw values with depth, explained as the result of a Rayleigh fractionation (e.g. Ripperger et al., 2007; Abouchami et al., 2014).

Cadmium concentrations and $\mathrm{Cd}$ isotope compositions of the Fazenda Funil stromatolites show a strong negative correlation $\left(r^{2}=0.85\right.$, dashed black line, Fig. 7a) with a fractionation factor $\alpha=1.00046$ (see electronic supplement for further information), twice as high as the fractionation observed in the Southern Ocean $(\alpha=1.0002$; Abouchami et al., 2014). Taking carbonate endmember I as a possible endmember for Paranoá seawater during the Late Mesoproterozoic, the fractionation curves of the calculated ambient fluid and the instantaneously precipitated carbonate can be calculated using the fractionation factor $\alpha$ (Fig. 7b). Because it is impossible to reconstruct the Cd concentration of the fluid at the moment of carbonate formation, we calculated $f$, i.e. the fraction of $\mathrm{Cd}$ incorporated into the carbonate relative to the highest measured concentration in our sample suite $(27 \mathrm{ng} / \mathrm{g}$; see electronic supplement for more information). A kinetic fractionation of $\mathrm{Cd}$ isotopes during 
567 incorporation into the carbonate lattice, where it substitutes for $\mathrm{Ca}$, leads to an offset of at 568 least $-2.27 \varepsilon$ units between $\mathrm{Cd}$ in the carbonate and $\mathrm{Cd}$ in the fluid $\left(=\Delta \varepsilon^{112 / 110} \mathrm{Cd} \mathrm{d}_{\text {fluid-calcite }}\right.$ in 569 saline water experiments; Horner et al., 2011; Fig. 7a, b). We emphasize that the large offset 570 in $\varepsilon^{112 / 110} \mathrm{Cd}$ values between modern deep ocean water (+1.17; Ripperger et al., 2007) and 571 our lowest obtained value $(-3.52)$ as well as the large $\alpha$ fractionation factor of the Rayleigh 572 curve that is larger than the $\alpha$ of enzymatic uptake in the ocean observed in the Fazenda 573 Funil stromatolites must be the result of a kinetic isotope effect of the prevailing Cd574 immobilization process, perhaps modified by fractionation during carbonate precipitation (see 575 Rayleigh fraction curves for single biotic or abiotic fractionation as grey shading in Fig. 7b). 576 Hence, the measured Cd concentrations and isotopic compositions in combination with trace 577 element systematics of stromatolitic carbonates provide unique high-resolution snapshots 578 into local Late Mesoproterozoic Paranoá stromatolite (micro)environments and allow 579 reconstructing redox conditions and potential microbial metabolisms of early life on Earth.

581 6. Conclusions

582 Stromatolites from the Mesoproterozoic Paranoá Group (Brazil) show REY 583 distributions and $\mathrm{Cd}$ isotope compositions in the carbonate phase that are devoid of detrital 584 contamination and post-depositional alteration. These carbonates thus provide a 585 geochemical archive of biogeochemical conditions in a shallow marine to coastal 586 environment during the Late Mesoproterozoic. REY $Y_{S N}$ patterns differentiate two contrasting 587 habitats in which the stromatolites formed: Conical stromatolites (conophyta) from Fazenda Funil formed in a depositional milieu that was in continuous exchange with open ocean water. Domal stromatolites from São Gabriel formed in a shallow-water lagoon that had restricted exchange of water with the open ocean and was dominated by REY input of the 591 weathered hinterland. Up to $25 \%$ higher REY concentrations in stromatolitic carbonates 592 relative to adjacent sedimentary carbonate might be due to a microbially mediated 593 enrichment process, suggesting REY as possible biomarker in stromatolitic carbonates. 
595 both localities indicate oxidizing atmospheric-hydrospheric conditions and no influence of 596 high-temperature hydrothermal fluids on the Late Mesoproterozoic Paranoá Group 597 environments.

598 Cadmium isotope values in the São Gabriel stromatolites overlap with values of the 599 upper continental crust suggesting that $\mathrm{Cd}$ was derived from continental weathering. In contrast, $\varepsilon^{112 / 110} \mathrm{Cd}$ dol values strongly vary at Fazenda Funil, showing a linear correlation with Mn and $\mathrm{Ce}$, and an inverse correlation with $\mathrm{Cd}$ and $\mathrm{U}$. Carbonates that precipitated under oxic conditions at the mat surface show low $\varepsilon^{112 / 110} \mathrm{Cd}_{\mathrm{dol}}$ values and low $\mathrm{Mn}$ and $\mathrm{Ce}$ concentrations but high $\mathrm{Cd}$ and $\mathrm{U}$ concentrations. Carbonates precipitated in the interior of the mat show increasing $\mathrm{Mn}$ and Ce concentrations due to the reductive dissolution of $\mathrm{Mn}$ oxides and colloids. We suggest that authigenic carbonate formed within a redox gradient in microbial mats where $\mathrm{U}$ and $\mathrm{Cd}$ are immobilized under reducing conditions. Light $\mathrm{Cd}$ isotopes are preferentially incorporated into $\mathrm{Cd}$ sulfides or adsorbed onto organic matter, leaving the ambient pore-fluid enriched in heavy $\mathrm{Cd}$ isotopes. Then, a positive $\varepsilon^{112 / 110} \mathrm{Cd} d \mathrm{~d}$ signature is preserved in authigenic carbonate minerals. Hence, the combination of trace elements and $\mathrm{Cd}$ isotope analyses may serve as a very useful multi-proxy approach to reconstruct biogeochemical conditions in ancient microbial mats and metal cycling of the earliest microbial communities on Earth.

\section{Acknowledgements}

We greatly acknowledge E. M. Guimaraes und T. R. Fairchild for organizing and leading the fieldtrip to São Gabriel and Fazenda Funil as part of the workshop on molecular fossils and acritarchs from Neoproterozoic and Lower Paleozoic in Brasília in 2013. We would like to thank the team of the Max Planck Institute for Chemistry, Climate Geochemistry Department, for their assistance in the laboratory and in operating the TIMS, along with S. Gier from the University of Vienna for help with the XRD analyses. We also acknowledge an anonymous reviewer for providing comments that helped to improve the manuscript significantly. 
S.V. has received funding from the European Union's Horizon 2020 research and

innovation program under the Marie Sklodowska-Curie project ELEMIN [grant no. 746033].

S.V.H. has been funded by the young international scientist fund by the National Science Foundation of China [funding Nos. 41650110480 and 41750410690 ].

\section{References}

Abouchami, W., Galer, S.J.G., de Baar, H.J.W., Middag, R., Vance, D., Zhao, Y., Klunder, M., Mezger, K., Feldmann, H., Andreae, M.O., 2014. Biogeochemical cycling of cadmium isotopes in the Southern Ocean along the Zero Meridian. Geochimica et Cosmochimica Acta 127, 348-367. doi:10.1016/j.gca.2013.10.022

Abouchami, W., Galer, S.J.G., Horner, T.J., Rehkämper, M., Wombacher, F., Xue, Z., Lambelet, M., Gault-Ringold, M., Stirling, C.H., Schönbächler, M., Shiel, A.E., Weis, D., Holdship, P.F., 2012. A Common Reference Material for Cadmium Isotope Studies NIST SRM 3108. Geostandards and Geoanalytical Research 37, 5-17. doi:10.1111/j.1751-908X.2012.00175.x

Albarède, F. 1995. Introduction to geochemical modeling. pp. 543, Cambridge Univ. Press, New York.

Allwood, A., Kamber, B., Walter, M., Burch, I., Kanik, I., 2010. Trace elements record depositional history of an Early Archean stromatolitic carbonate platform. Chem. Geol. 270, 148-163. doi:10.1016/j.chemgeo.2009.11.013

Alvarenga, C.J.S., Santos, R. V., Vieira, L.C., Lima, B.A.F., Mancini, L.H., 2014. MesoNeoproterozoic isotope stratigraphy on carbonates platforms in the Brasilia Belt of Brazil. Precambrian Res. 251, 164-180. doi:10.1016/j.precamres.2014.06.011

Barbosa, J. F. S., Peucat, J. J., Martin, H., da Silva, F. A., de Moraes, A. M., Corrêa-Gomes, L. C., ... Fanning, C. M., 2008. Petrogenesis of the late-orogenic Bravo granite and surrounding high-grade country rocks in the Palaeoproterozoic orogen of ItabunaSalvador-Curaçá block, Bahia, Brazil. Precambrian Research, 167(1-2), 35-52. https://doi.org/10.1016/j.precamres.2008.06.002

Bau, M., Dulski, P., 1996. Distribution of yttrium and rare-earth elements in the Penge and Kuruman iron-formations, Transvaal Supergroup, South Africa. Precambrian Res. 79, 37-55. doi:10.1016/0301-9268(95)00087-9

Bau, M., Dulski, P., 1999. Comparing yttrium and rare earths in hydrothermal fluids from the Mid-Atlantic Ridge: Implications for $Y$ and REE behaviour during near-vent mixing and for the Y/Ho ratio of Proterozoic seawater. Chemical Geology, 155(1-2), 77-90. https://doi.org/10.1016/S0009-2541(98)00142-9 
Birgel, D., Meister, P., Lundberg, R., Horath, T. D., Bontognali, T. R. R., Bahniuk, A. M., ... Mckenzie, J. A. 2015. Methanogenesis produces strong 13C enrichment in stromatolites of Lagoa Salgada, Brazil: A modern analogue for Palaeo-/Neoproterozoic stromatolites? Geobiology, 13(3), 245-266. https://doi.org/10.1111/gbi.12130

Bolhar, R., Van Kranendonk, M. J. 2007. A non-marine depositional setting for the northern Fortescue Group, Pilbara Craton, inferred from trace element geochemistry of stromatolitic carbonates. Precambrian Research, 155(3-4), 229-250. https://doi.org/10.1016/j.precamres.2007.02.002

Boyle, E.A., Sclater, F., Edmond, J.M., 1976. On the marine geochemistry of cadmium. Nature 263, 42-44.

Breitenbach, S.F.M. and Bernasconi, S.M. (2011) Carbon and oxygen isotope analysis of small carbonate samples (20 to $100 \mu \mathrm{g}$ ) with a GasBench II preparation device. Rapid Commun. Mass Spectrom. 25, 1910-1914.

Campos, J.E.G., Bogossian, J., Carvalho, R.M., 2012. Sedimentology of the Psammo-peliticcarbonate Unit, Paranoá Group, and Sete Lagoas Formation, Bambuí Group: examples of mixed carbonate- siliciclastic sedimentation in the Proterozoic of the Brasília Fold Belt. Rev. Bras. da Geociências 42, 513-522. doi:10.5327/Z037575362012000300006

de Baar, H. J. W., van Heuven, S. M. A. C., Abouchami, W., Xue, Z., Galer, S. J. G., Rehkämper, M., et al. (2017). Interactions of dissolved CO2 with cadmium isotopes in the Southern Ocean. Marine Chemistry, 195, 105-121. http://doi.org/10.1016/j.marchem.2017.06.010

Douville, E., Charlou, J.L., Oelkers, E.H., Bienvenu, P., Jove Colon, C.F., Donval, J.P.,Fouquet, Y., Prieur, D., Appriou, P., 2002. The rainbow vent fluids (36_140N, MAR): the influence of ultramafic rocks and phase separation on trace metal content in Mid-Atlantic Ridge hydrothermal fluids. Chem. Geol. 184, 37-48. http://dx.doi.org/10.1016/S0009-2541(01)00351-5.

Fairchild et al, 1996. Recent discoveries of Proterozoic microfossils in south-central Brazil. Precambrian Res. 80, 125-152. doi:10.1016/S0301-9268(96)00009-5

Fuck, R.A., Marini, O.J., Dardenne, M.A., Figueiredo, A.N., 1988. Coberturas metassedimentares do Proterozoico Medio:Os grupos Arai e Paranoa na regiao de Niquelandia-Colinas, Goias. Rev. Brasil. Geocien., 18, 54-62

Georgiev, S.V., Horner, T.J., Stein, H.J., Hannah, J.L., 2015. Cadmium-isotopic evidence for increasing primary productivity during the Late Permian anoxic event. Earth and Planetary Science Letters 410, 84-96. doi:10.1016/j.epsl.2014.11.010

Guinoiseau, D., Galer, S. J. G., \& Abouchami, W. (2018). Effect of cadmium sulphide precipitation on the partitioning of $\mathrm{Cd}$ isotopes: Implications for the oceanic $\mathrm{Cd}$ cycle. 
http://doi.org/10.1016/j.epsl.2018.06.039

Hollander, D. J., \& McKenzie, J. A., 1991. Co2 Control on Carbon-Isotope Fractionation During Aqueous Photosynthesis - a Paleo-Pco2 Barometer. Geology, 19(9), 929-932.

Hohl, S.V., Becker, H., Herzlieb, S., Guo, Q., 2015. Multiproxy constraints on alteration and primary compositions of Ediacaran deep-water carbonate rocks, Yangtze Platform, South China. Geochimica et Cosmochimica Acta 163, 262-278. doi:10.1016/j.gca.2015.04.037 Hohl, S.V., Galer, S.J.G., Gamper, A., Becker, H., 2017. Cadmium isotope variations in Neoproterozoic carbonates - A tracer of biologic production? Geochem. Persp. Let. 3244. doi:10.7185/geochemlet.1704

Horner, T.J., Rickaby, R.E.M., Henderson, G.M., 2011. Isotopic fractionation of cadmium into calcite. Earth and Planetary Science Letters 312, 243-253. doi:10.1016/j.epsl.2011.10.004

John, S.G., Kunzmann, M., Townsend, E.J., Rosenberg, A.D., 2016. Zinc and cadmium stable isotopes in the geological record: A case study from the post-snowball Earth Nuccaleena cap dolostone. Palaeogeography, Palaeoclimatology, Palaeoecology. doi:10.1016/j.palaeo.2016.11.003

Kah, L.C., Bartley, J.K., Stagner, A.F., 2009. Reinterpreting a Proterozoic enigma: Conophyton-Jacutophyton stromatolites of the Mesoproterozoic Atar Group, Mauritania. Int. Assoc. Sedimentol. Spec. Publ. 277-296.

Kamber, B.S., Bolhar, R., Webb, G.E., 2004. Geochemistry of late Archaean stromatolites from Zimbabwe: evidence for microbial life in restricted epicontinental seas. Precambrian Res. 132, 379-399. doi:10.1016/j.precamres.2004.03.006

Kamber, B.S., Webb, G.E., Gallagher, M., 2014. The rare earth element signal in Archaean microbial carbonate: information on ocean redox and biogenicity. J. Geol. Soc. London. 171, 745-763. doi:10.1144/jgs2013-110

Lacan, F., Francois, R., Ji, Y., Sherrell, R.M., 2006. Cadmium isotopic composition in the ocean. Geochimica et Cosmochimica Acta 70, 5104-5118. doi:10.1016/j.gca.2006.07.036

Lambelet, M., Rehkämper, M., van de Flierdt, T., Xue, Z., Kreissig, K., Coles, B., Porcelli, D., Andersson, P., 2013. Isotopic analysis of $\mathrm{Cd}$ in the mixing zone of Siberian rivers with the Arctic Ocean-New constraints on marine Cd cycling and the isotope composition of riverine Cd. Earth and Planetary Science Letters 361, 64-73. doi:10.1016/j.epsl.2012.11.034

Matteini, M., Dantas, E. L., Pimentel, M. M., de Alvarenga, C. J. S., \& Dardenne, M. A., 2012. $\mathrm{U}-\mathrm{Pb}$ and $\mathrm{Hf}$ isotope study on detrital zircons from the Paranoá Group, Brasília Belt Brazil: Constraints on depositional age at Mesoproterozoic - Neoproterozoic transition 
and tectono-magmatic events in the São Francisco craton. Precambrian Research, 206207, 168-181. https://doi.org/10.1016/j.precamres.2012.03.007

Martin, W., Russell, M.J., 2007. On the origin of biochemistry at an alkaline hydrothermal vent. Philos. Trans. R. Soc. Lond. B. Biol. Sci. 362, 1887-925. doi:10.1098/rstb.2006.1881

Middag, R., van Heuven, S.M.A.C., Bruland, K.W., de Baar, H.J.W., 2018. The relationship between cadmium and phosphate in the Atlantic Ocean unravelled. Earth Planet. Sci. Lett. 492, 79-88. https://doi.org/10.1016/j.epsI.2018.03.046

Nothdurft, L.D., Webb, G.E., Kamber, B.S., 2004. Rare earth element geochemistry of Late Devonian reefal carbonates, Canning Basin, Western Australia: confirmation of a seawater REE proxy in ancient limestones. Geochimica et Cosmochimica Acta 68, 263283. doi:10.1016/S0016-7037(03)00422-8

Nutman, A.P., Bennett, V.C., Friend, C.R.L., Van Kranendonk, M.J., Chivas, A.R., 2016. Rapid emergence of life shown by discovery of 3,700-million-year-old microbial structures. Nature 537, 535-538. doi:10.1038/nature19355

Pimentel, M.M., Fuck, R.A., 1992 Neoproterozoic crustal accretion in central Brazil. doi:10.1130/0091-7613(1992)020<0375

Pimentel, M.M., Fuck, R.A., Botelho, N.F., 1999. Granites and the geodynamic history of the Neoproterozoic Brasilia belt, Central Brazil: A review. Lithos 46, 463-483. doi:10.1016/S0024-4937(98)00078-4

Pimentel, M.M., Rodrigues, J.B., DellaGiustina, M.E.S., Junges, S., Matteini, M., Armstrong, R., 2011. The tectonic evolution of the Neoproterozoic Brasília Belt, central Brazil, based on SHRIMP and LA-ICPMS U-Pb sedimentary provenance data: A review. J. South Am. Earth Sci. 31, 345-357. doi:10.1016/j.jsames.2011.02.011

Ripperger, S., Rehkämper, M., Porcelli, D., \& Halliday, A. N. (2007). Cadmium isotope fractionation in seawater - A signature of biological activity. Earth and Planetary Science Letters, 261(3-4), 670-684.

Rodler, A. S., Hohl, S. V., Guo, Q., \& Frei, R. (2016). Chromium isotope stratigraphy of Ediacaran cap dolostones, Doushantuo Formation, South China. Chemical Geology, 436, 24-34. http://doi.org/10.1016/j.chemgeo.2016.05.001

Rosman, K.J.R., De Laeter, J.R., Gorton, M.P., 1980. Cadmium isotope fractionation in fractions of two H3 chondrites. Earth and Planetary Science Letters 48, 166-170. doi:10.1016/0012-821X(80)90179-X

Schmitt, A.-D., Galer, S.J.G., Abouchami, W., 2009a. High-precision cadmium stable isotope measurements by double spike thermal ionisation mass spectrometry. J. Anal. At. Spectrom. 24, 1079. doi:10.1039/b821576f

Schmitt, A.-D., Galer, S.J.G., Abouchami, W., 2009b. Mass-dependent cadmium isotopic variations in nature with emphasis on the marine environment. Earth and Planetary 


\section{Science Letters 277, 262-272. doi:10.1016/j.epsl.2008.10.025}

Schier, K., Bau, M., Münker, C., Beukes, N., Viehmann, S., 2018. Trace element and Nd isotope composition of shallow seawater prior to the Great Oxidation Event: Evidence from stromatolitic bioherms in the Paleoproterozoic Rooinekke and Nelani Formations, South Africa. Precambrian Res. 315, 92-102. https://doi.org/10.1016/j.precamres.2018.07.014

Tepe, N., Bau, M., 2016. Behavior of rare earth elements and yttrium during simulation of arctic estuarine mixing between glacial-fed river waters and seawater and the impact of inorganic (nano-)particles. Chemical Geology, 438, 134-145. https://doi.org/10.1016/j.chemgeo.2016.06.001

Tribovillard, N., Algeo, T. J., Lyons, T., \& Riboulleau, A., 2006. Trace metals as paleoredox and paleoproductivity proxies: An update. Chemical Geology, 232(1-2), 12-32. https://doi.org/10.1016/j.chemgeo.2006.02.012

Vasconcelos, C., Warthmann, R., McKenzie, J. A., Visscher, P. T., Bittermann, A. G., \& Van Lith, Y. (2006). Lithifying microbial mats in Lagoa Vermelha, Brazil: Modern Precambrian relics? Sedimentary Geology, 185(3-4), 175-183. http://doi.org/10.1016/j.sedgeo.2005.12.022

Viehmann, S., Bau, M., Hoffmann, J.E., Münker, C., 2015. Geochemistry of the Krivoy Rog Banded Iron Formation, Ukraine, and the impact of peak episodes of increased global magmatic activity on the trace element composition of Precambrian seawater. Precambrian Res. 270, 165-180. doi:10.1016/j.precamres.2015.09.015

Viehmann, S., Bau, M., Bühn, B., Dantas, E.L., Andrade, F.R.D., Walde, D.H.G., 2016. Geochemical characterisation of Neoproterozoic marine habitats: Evidence from trace elements and $\mathrm{Nd}$ isotopes in the Urucum iron and manganese formations, Brazil. Precambrian Res. 282, 74-96. doi:10.1016/j.precamres.2016.07.006

Webb, G.E., Kamber, B.S., 2000. Rare earth elements in Holocene reefal microbialites: a new shallow seawater proxy. Geochim. Cosmochim. Acta 64, 1557-1565. doi:10.1016/S0016-7037(99)00400-7

Webb, G.E., Kamber, B.S., 2010. Trace Element Geochemistry as a Tool for Interpreting Microbialites in Earliest Life on Earth: Habitats, Environments and Methods of Detection (eds. Golding, S.D., Glikson). doi:10.1007/978-90-481-8794-2

Webb GE, Nothdurft LD, Kamber BS, Kloprogge JT, Zhao J-X, 2009. Rare earth element geochemistry of scleractinian coral skeleton during meteoric diagenesis: a sequence through neomorphism of aragonite to calcite. Sedimentology 56:1433-1463

Weiss, M.C., Sousa, F.L., Mrnjavac, N., Neukirchen, S., Roettger, M., Nelson-Sathi, S., Martin, W.F., 2016. The physiology and habitat of the last universal common ancestor. Nat. Microbiol. 1, 16116. doi:10.1038/nmicrobiol.2016.116 
Xie, R.C., Galer, S.J.G., Abouchami, W., Rijkenberg, M.J.A., de Baar, H.J.W., De Jong, J., Andreae, M.O., 2017. Non-Rayleigh control of upper-ocean Cd isotope fractionation in the western South Atlantic. Earth and Planetary Science Letters 471, 94-103. doi:10.1016/j.epsl.2017.04.024

Yeghicheyan, D., Carignan, J., Valladon, M., Bouhnik Le Coz, M., Samuel, J., BenBakkar, M., et al. (2003). The new carbonate reference material Cal-S: preliminary results. Abs. Geoanal, 2003, 146. http://doi.org/10.1029/2009GC002899/full

\section{Figure Captions}

816 Figure 1. (a) Geological map of the Brasilia Belt with the Paranoá Group showing the 817 sampling locations at São Gabriel and Fazenda Funil (modified from Fairchild et al., 1996). (b) 818 Stratigraphic column of the Paranoá Group showing the intervals of transgression and 819 regression and the stratigraphic positions of the domal stromatolites at São Gabriel and the 820 conophyton-type stromatolites of Fazenda Funil.

821 Figure 2. Photographs of stromatolites from São Gabriel and Fazenda Funil. (a) Vertical 822 section of dome-shaped stromatolites from São Gabriel showing homogeneous carbonate 823 infill between individual stromatolites. The stacked laminae reach a thickness of $4.5 \mathrm{~cm}$, 824 although the actual relief above the sediment surface may have been no more than a 825 centimeter. Micro-laminae are $<2 \mathrm{~mm}$ in thickness. (b) Vertical section of stromatolites of the

828 Figure 3. Graphs showing the concentrations of $\mathrm{Er}$ and $\varepsilon^{112 / 110} \mathrm{Cd}$ dol values plotted versus $\mathrm{Sr}$ 829 and $\mathrm{Zr}$ concentrations and $\delta^{18} \mathrm{O}_{\text {dol }}$ values measured in leachates (full symbols) and full 830 digestions (open symbols) of stromatolites from São Gabriel (red) and Fazenda Funil (blue). 831 Squares indicate values from carbonate outside the stromatolites. Both stromatolitic 832 carbonate suites are devoid of detrital contamination and post-depositional alteration, but the 833 elemental and isotopic values are significantly different. 
834 Figure 4. REYSN patterns of stromatolites from São Gabriel and Fazenda Funil. (a) REYSN 835 patterns of conophyton-type stromatolites from Fazenda Funil are sub-parallel to those of 836 modern seawater (multiplied by $10^{5}$; Douville et al., 2002). They do not show similarity with 837 REY $_{S N}$ patterns from high-temperature fluids (Bau \& Dulski, 1999). (b) REY 838 domal stromatolites from São Gabriel are sub-parallel to patterns measured in Late Archean 839 Mushandike stromatolites (Kamber et al., 2004). The REY patterns of São Gabriel 840 stromatolites normalized to concentrations of Paleo-proterozoic plutonic rocks from the São 841 Francisco Craton (Barbosa et al., 2008) are sub-parallel to modern seawater. At both sites, 842 REY concentrations and REY $\mathrm{SN}_{\text {patterns of nitric acid-leachates and fully digested samples }}$ $843\left(\mathrm{HNO}_{3}-\mathrm{HCl}-\mathrm{HF}\right.$ mixture $)$ overlap.

844 Figure 5. Palaeo-environmental model for the stromatolites of the Paranoá Group. Domal 845 stromatolites of the São Gabriel location were deposited in a shallow-water environment with 846 limited supply of seawater. Conophyton-type stromatolites were deposited in the photic zone 847 in an open shelf environment. The inset shows a conceptual model for the formation of 848 different types of carbonate laminae in different redox zones within the microbial mat.

849 Figure 6. $\delta^{13} \mathrm{C}_{\text {dol }}(\mathrm{a}), \mathrm{U}(\mathrm{b})$ and $\mathrm{Mn}$ concentrations (c) as well as $\mathrm{Ce}_{\mathrm{SN}} / \mathrm{Ce}_{\mathrm{SN}}{ }^{*}$ ratios (d) plotted relative to $\varepsilon^{112 / 110} \mathrm{Cd}$ dol compositions obtained in acetic acid-leachates of stromatolites from 851 the Paranoá Group. While no correlation between Cd and C isotopes are observed, negative 852 correlations between $\varepsilon^{112 / 110} \mathrm{Cd}$ dol and $U$ concentrations in the Fazenda Funil stromatolites 853 coincide with positive correlations to $\mathrm{Ce}_{\mathrm{SN}} / \mathrm{Ce}^{*}{ }_{\mathrm{SN}}$ ratios and $\mathrm{Mn}$ concentrations. The most positive $\varepsilon^{112 / 110} \mathrm{Cd}$ ratios correlate with enrichments of $\mathrm{Mn}$ and $\mathrm{Ce}$ concentrations as well as depletions in $U$ concentrations.

Figure 7. Plot of $\varepsilon^{112 / 110} \mathrm{Cd}$ dol versus $\mathrm{Cd}$ concentrations (a) and $f$, i.e. the fraction of $\mathrm{Cd}$ incorporated into the carbonate lattice (b). (a) Cd isotope values show a negative correlation with Cd concentrations in acetic acid-leachates of the Fazenda Funil stromatolites $\left(r^{2}=0.85\right)$. The calculated Rayleigh fractionation curve for $\mathrm{Cd}$ incorporation into Fazenda Funil stromatolites yields a fractionation factor $\alpha$ of 1.00046 (dashed black line) that is twice as 
high as that found in the modern Southern Ocean $(\alpha=1.0002$, dashed green line; data taken 862 from ${ }^{1}$ Abouchami et al., 2014). The resulting Cd isotope composition for ambient fluid (dotted 863 black line) is calculated to have been higher by $2.27 \varepsilon$ units than the analyzed Cd isotopic 864 compositions due to kinetic Cd fractionation during incorporation into the carbonate lattice $865\left({ }^{4}\right.$ Horner et al., 2011) and it plots below modern deep ocean values $\left(+1.17,{ }^{2}\right.$ Ripperger et al., 866 2007). Stromatolites from São Gabriel show only a small fractionation of Cd isotope values 867 relative to average loess $\left(+0.04{ }^{3}\right.$ Schmitt et al., 2009b). (b) Calculated Rayleigh fractionation 868 curve for a given $f$, the fraction of $\mathrm{Cd}$ incorporated into the carbonate lattice relative to the 869 highest measured value in the sample suite, showing the calculated pore-fluid Cd 870 concentration and isotope composition (dotted line) yielding Cd isotope values as observed 871 in the modern ocean. The shaded areas show the Rayleigh curves for kinetic Cd 872 fractionation into carbonate and biological $\mathrm{Cd}$ uptake by phytoplankton in the modern 873 Southern Ocean, respectively.

876 Table 1. Major element oxides (wt \%), $\quad \delta^{18} \mathrm{O}_{\text {dol }}$ and $\delta^{13} \mathrm{C}_{\text {dol }}(\%$ V-PDB), trace element 877 concentrations (ppm), and trace element ratios of nitric acid-leachates and fully digested 878 samples of the domal stromatolites from São Gabriel.

879 Table 2. Major element oxides (wt \%), $\delta^{18} \mathrm{O}_{\text {dol }}$ and $\delta^{13} \mathrm{C}_{\text {dol }}(\%$ V-PDB), trace element 880 concentrations (ppm), and trace element ratios of nitric acid-leachates and fully digested 881 samples of conical conophyta from Fazenda Funil and the certified reference materials JDo-1 882 (Permian dolomite) and JLs-1 (Triassic limestone).

883 Table 3. Cadmium concentrations and isotopic compositions of acetic acid-leachates from 884 stromatolites of São Gabriel and Fazenda Funil, a Cambrian reefal stromatolite of the Bayan 885 Gol Formation (Altai, W.-Mongolia), and the Jurassic calcite standard CAL-S (Yeghicheyan 886 et al., 2003). The subscript "auth." stands for detrital input corrected concentrations and 887 isotopic compositions, respectively. For details see supplementary information. 


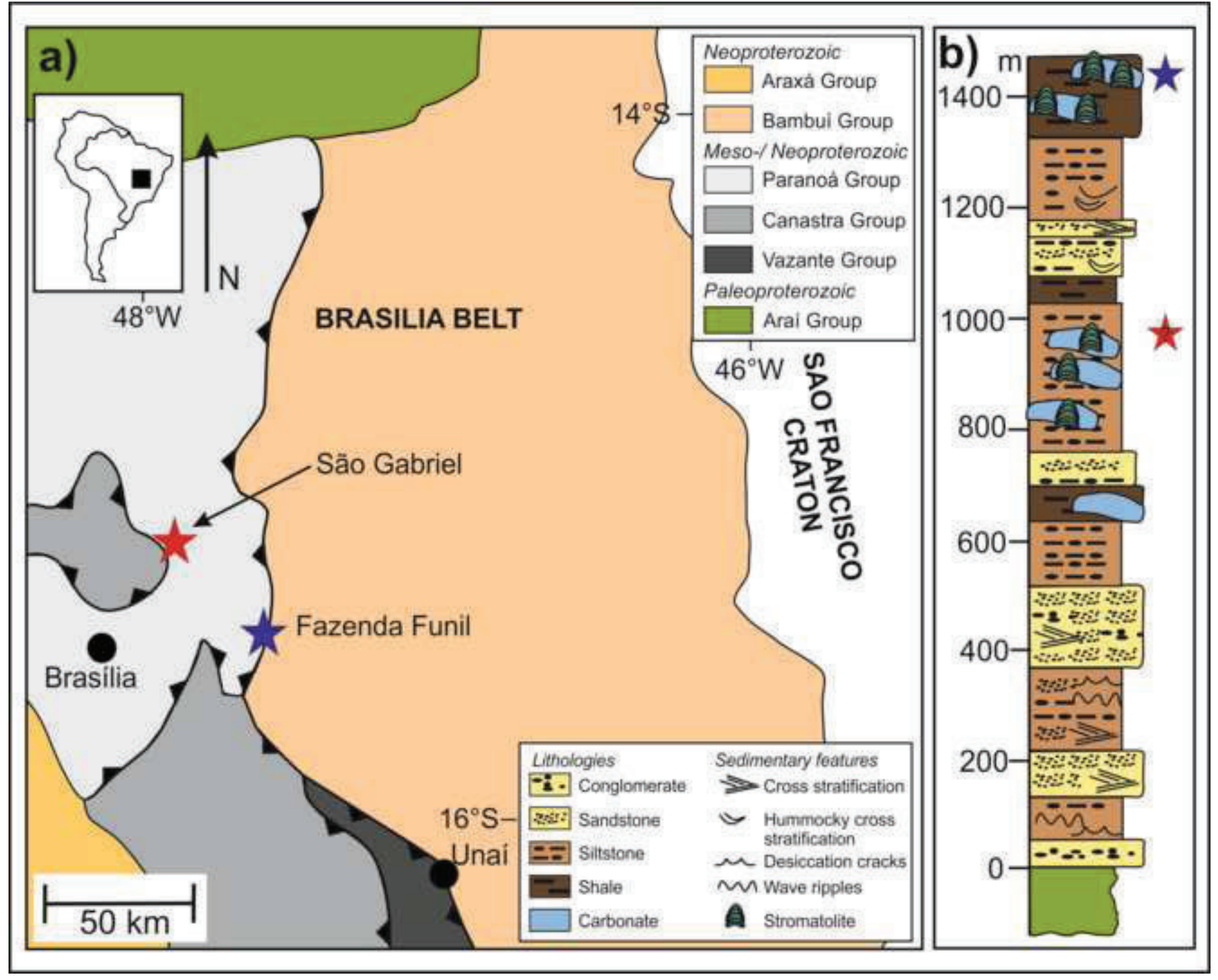



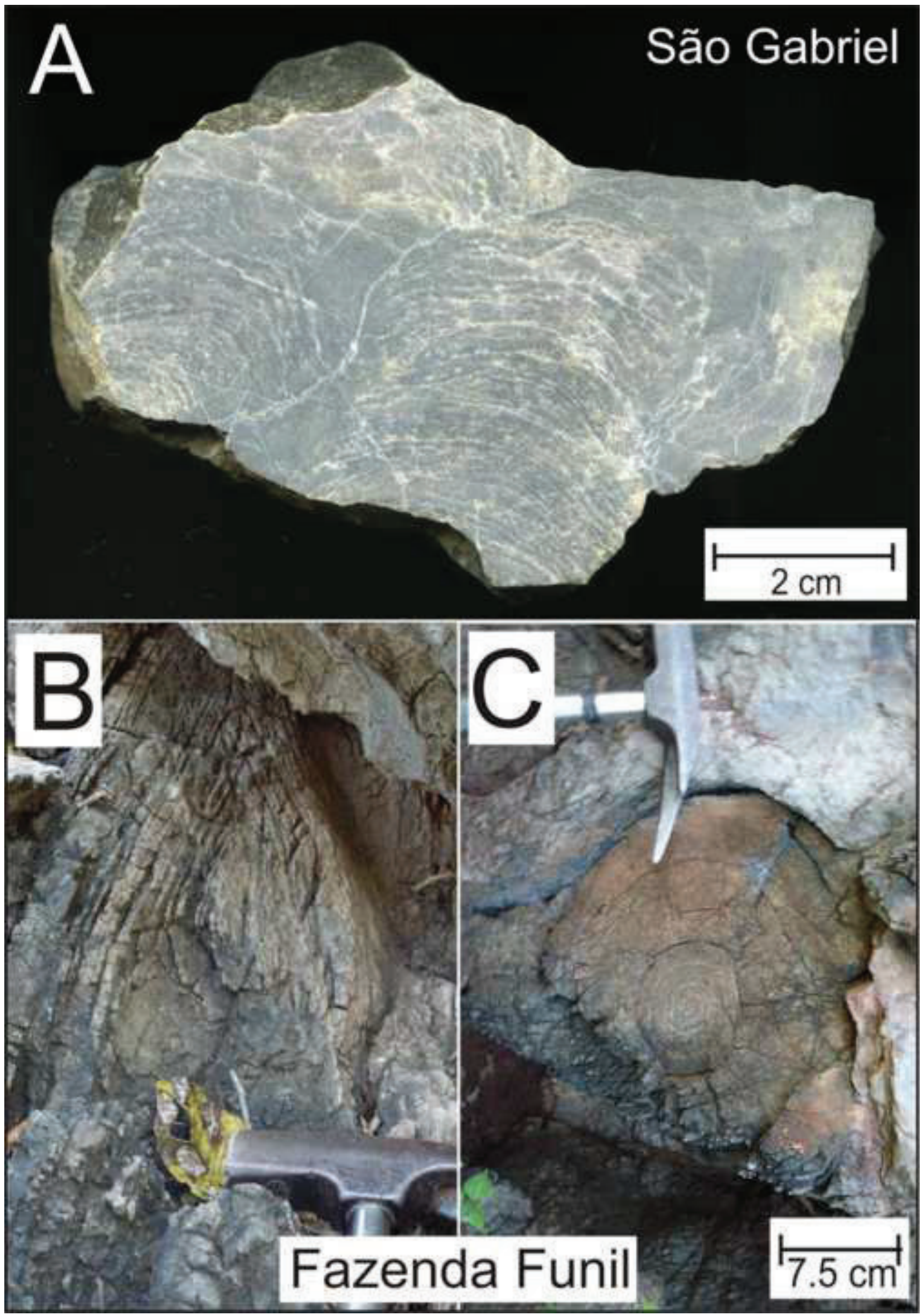

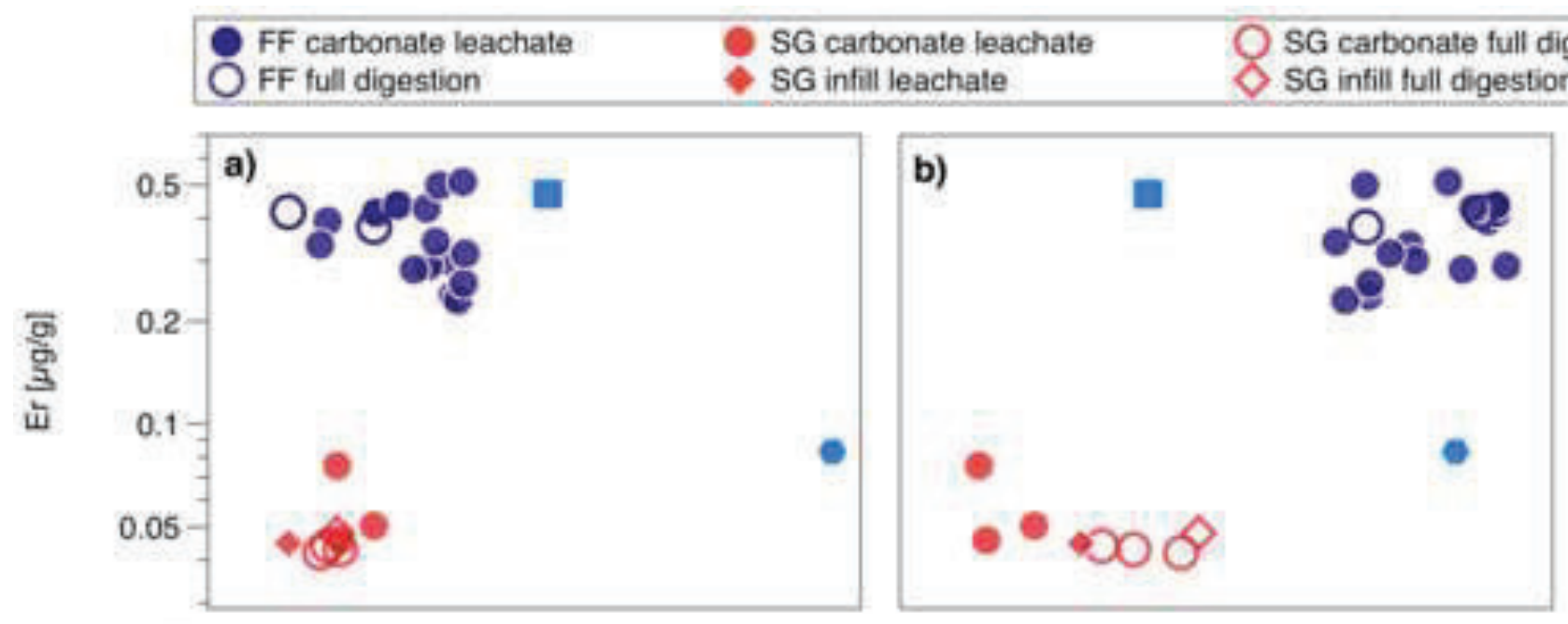

CAL-S Jurassic calcite std.
JDo-1 Permian dolomite std.
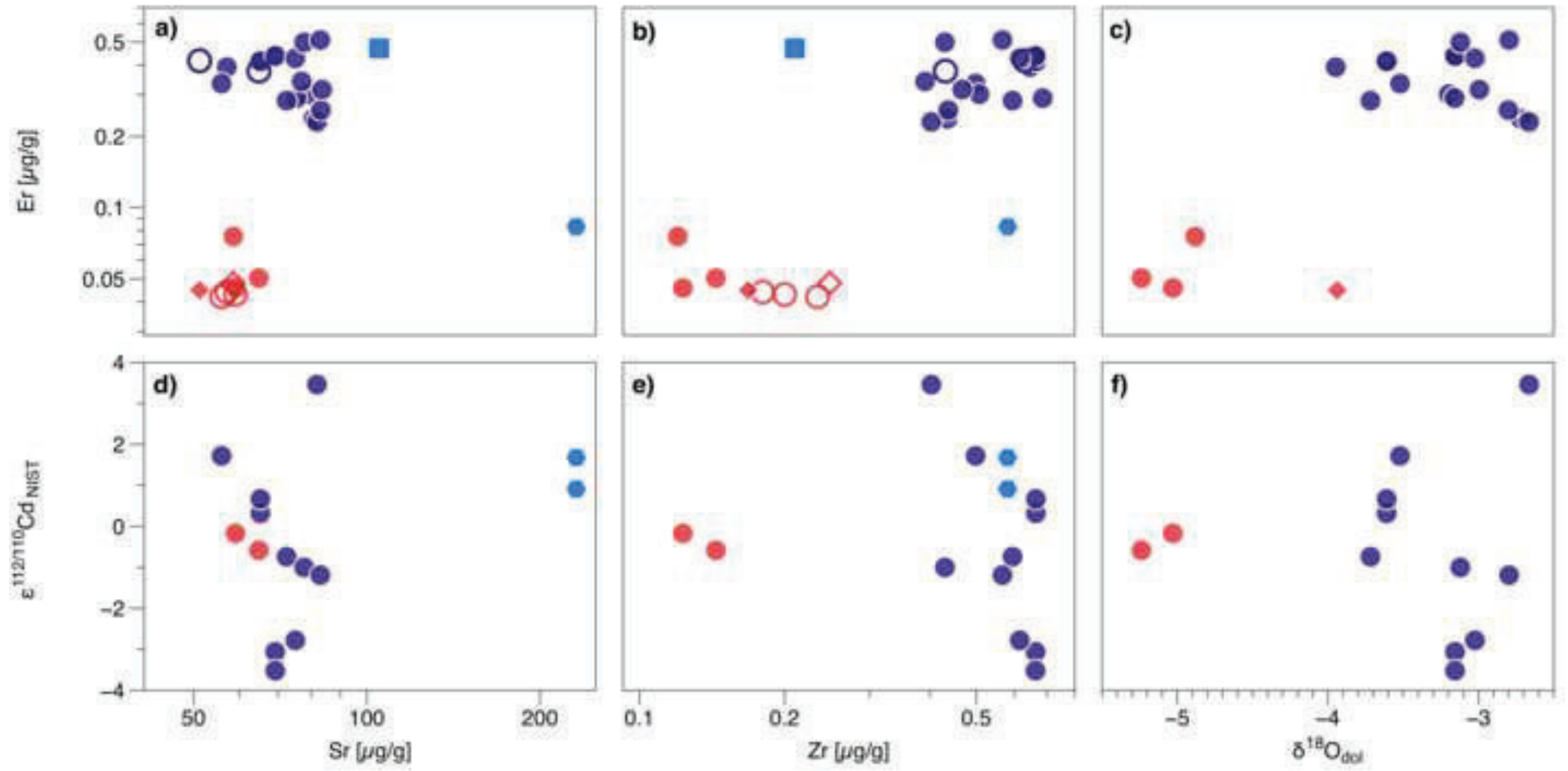

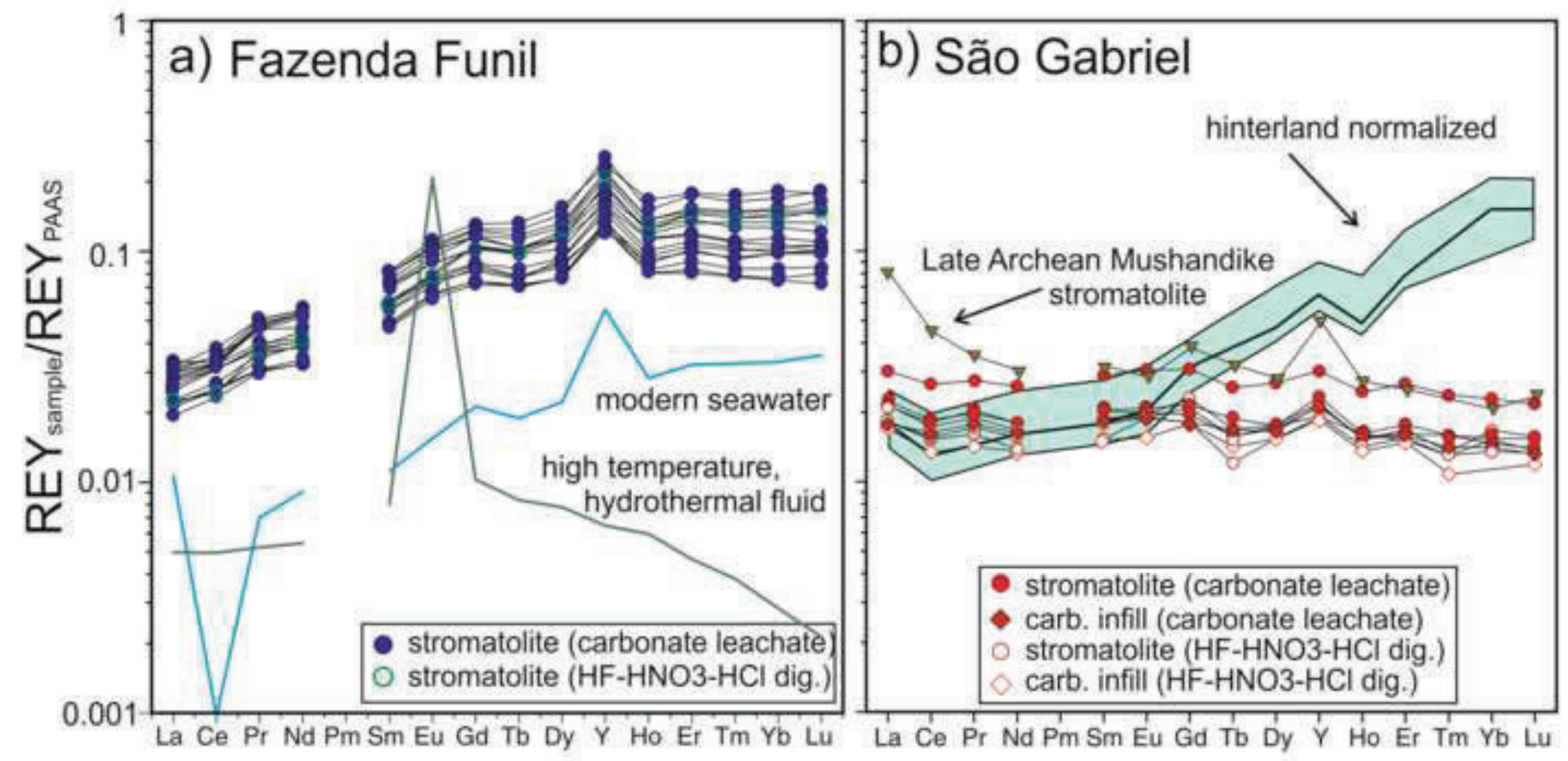


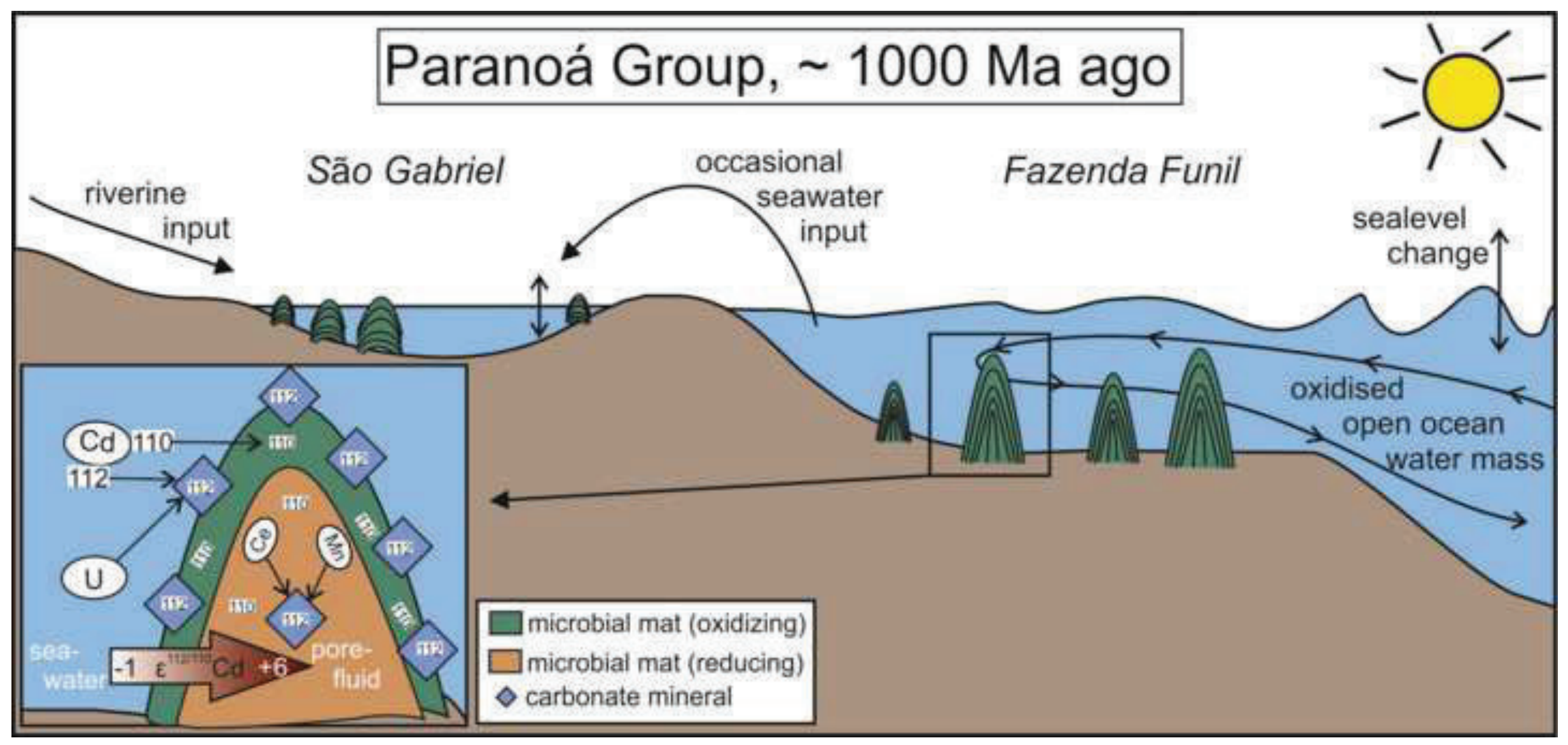



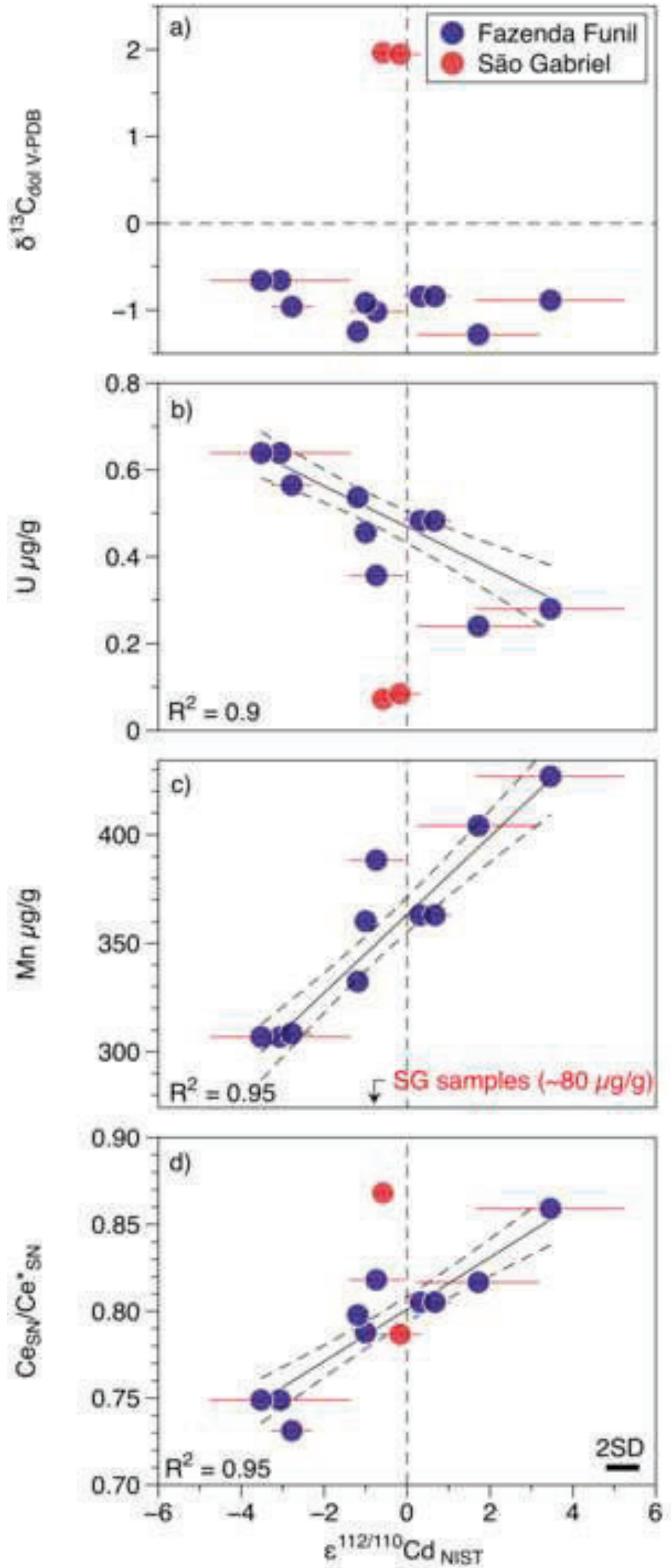


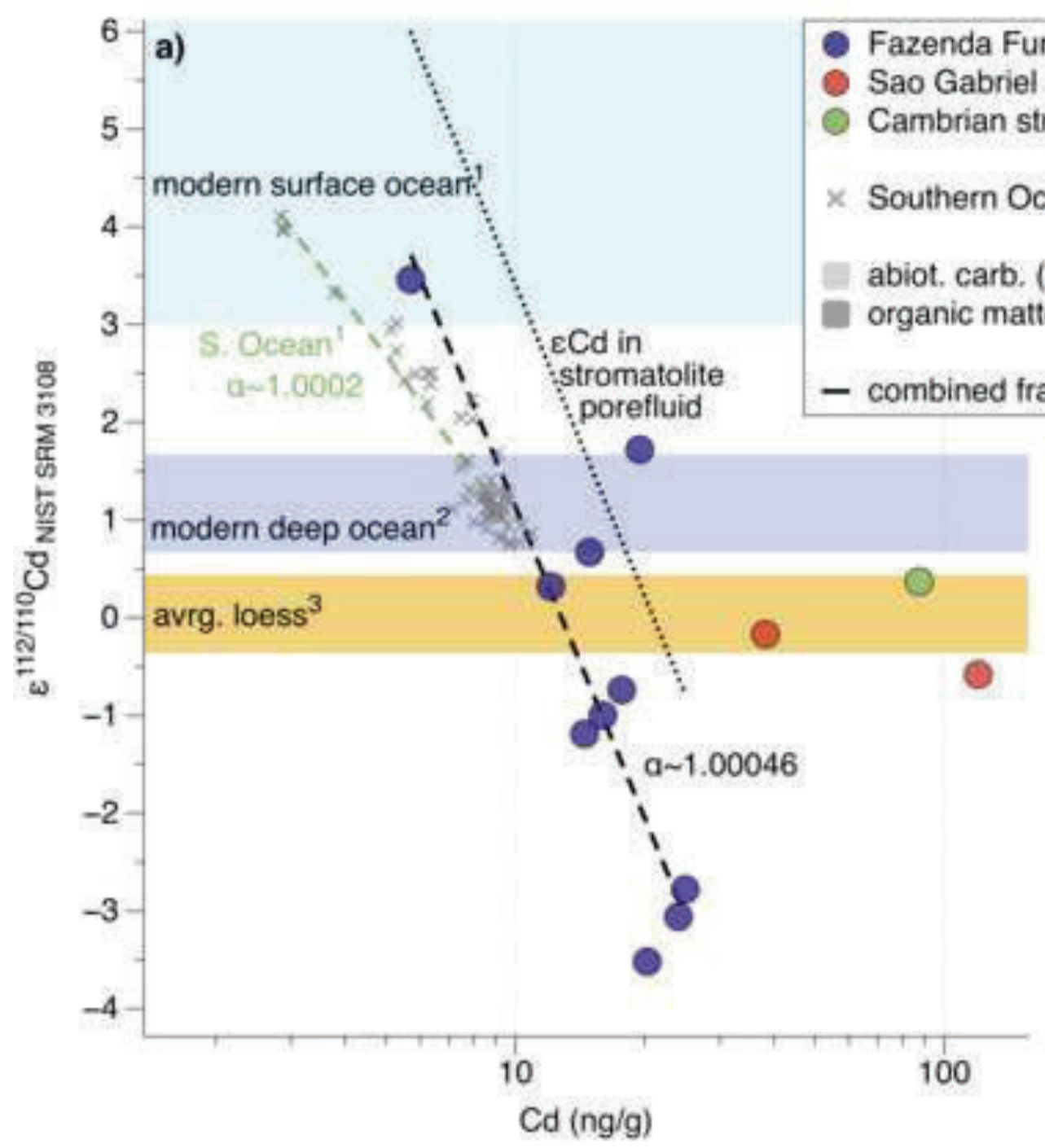

b)

Sazenda Funil stromatolites

Cambrian stromatolite

Southern Ocean $\left(\mathrm{Cd}^{*} 10^{2}\right)^{1}$

abiot. carb. $(a=1,00027)^{4}$

organic matter $(a=1.0002)^{1}$

combined fract. $(a=1.00046)$

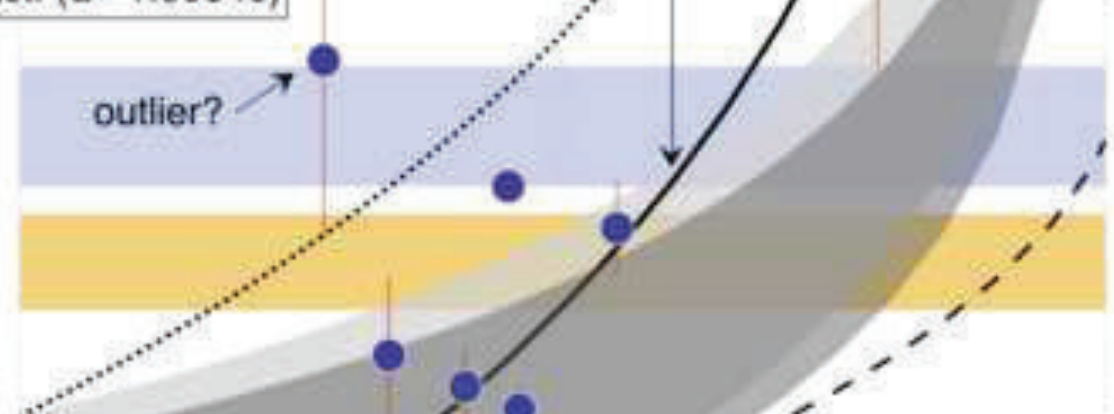

endmember 1

microbial mat/carbonate

interface

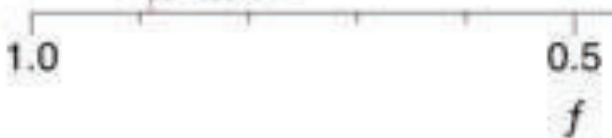


TABLE 1. MAJOR \& TRACE ELEMENT CONCENTRATIONS OF SAO GABRIEL STROMATOLITES

\begin{tabular}{|c|c|c|c|c|c|c|c|c|}
\hline sample-ID & BR_SG_10a & BR_SG_10b & BR_SG_10c & BR_SG_10d & BR_SG_STR1 & BR_SG_STR2 & BR_SG_STR3 & BR_SG_STR4 \\
\hline $\begin{array}{c}\text { type } \\
\text { digestion }\end{array}$ & $\begin{array}{c}\text { stromatolite } \\
\mathrm{HNO}_{3}\end{array}$ & $\begin{array}{c}\text { carb. infill } \\
\mathrm{HNO}_{3}\end{array}$ & $\begin{array}{c}\text { stromatolite } \\
\mathrm{HNO}_{3}\end{array}$ & $\begin{array}{c}\text { stromatolite } \\
\mathrm{HNO}_{3}\end{array}$ & $\begin{array}{c}\text { stromatolite } \\
\mathrm{HF}-\mathrm{HNO}_{3}-\mathrm{HCl}\end{array}$ & $\begin{array}{c}\text { stromatolite } \\
\mathrm{HF}-\mathrm{HNO}_{3}-\mathrm{HCl}\end{array}$ & $\begin{array}{c}\text { stromatolite } \\
\mathrm{HF}-\mathrm{HNO}_{3}-\mathrm{HCl}\end{array}$ & $\begin{array}{c}\text { carb. infill } \\
\mathrm{HF}-\mathrm{HNO}_{3}-\mathrm{HCl}\end{array}$ \\
\hline $\bar{w} w t \%$ & & & & & & & & \\
\hline $\mathrm{Al} 2 \mathrm{O} 3$ & 0.2 & 0.22 & 0.19 & 0.2 & & & & \\
\hline $\mathrm{CaO}$ & 28.1 & 29.1 & 29.4 & 29.5 & & & & \\
\hline $\mathrm{FeO}$ & 0.11 & 0.05 & 0.07 & 0.09 & & & & \\
\hline $\mathrm{Fe} 2 \mathrm{O} 3$ & 0.12 & 0.05 & 0.07 & 0.1 & & & & \\
\hline MgO & 20.2 & 20.6 & 21.0 & 20.7 & & & & \\
\hline MnO & 0.01 & 0.01 & 0.01 & 0.02 & & & & \\
\hline $13 \mathrm{C}$ & 2.0 & 2.1 & 1.9 & 1.9 & & & & \\
\hline \pm err & 0.1 & 0.1 & 0.1 & 0.1 & & & & \\
\hline 180 & -5.2 & -3.9 & -5.0 & -4.9 & & & & \\
\hline \pm err & 0.2 & 0.1 & 0.1 & 0.1 & & & & \\
\hline $\mathrm{mg} / \mathrm{kg}$ & & & & & & & & \\
\hline Sc & 0.169 & 0.203 & 0.172 & 0.284 & 0.199 & 0.235 & 0.206 & 0.2 \\
\hline $\mathrm{Ni}$ & 0.411 & 0.389 & 0.404 & 0.573 & $<L O Q$ & $<L O Q$ & $<L O Q$ & $<L O Q$ \\
\hline $\mathbf{R b}$ & 0.0845 & 0.103 & 0.076 & 0.0755 & 0.156 & 0.225 & 0.15 & 0.13 \\
\hline $\mathrm{Sr}$ & 64.9 & 51.2 & 59.1 & 58.6 & 57.1 & 57.9 & 51.9 & 55.6 \\
\hline $\mathbf{Y}$ & 0.629 & 0.578 & 0.569 & 0.816 & 0.516 & 0.59 & 0.518 & 0.501 \\
\hline $\mathrm{Zr}$ & 0.144 & 0.168 & 0.123 & 0.12 & 0.2 & 0.248 & 0.18 & 0.234 \\
\hline $\mathrm{Nb}$ & 0.00322 & 0.00498 & 0.00299 & 0.00352 & 0.0124 & 0.0185 & 0.0115 & 0.0162 \\
\hline Cs & 0.0215 & 0.0196 & 0.0184 & 0.0106 & 0.0246 & 0.0306 & 0.0159 & 0.024 \\
\hline $\mathrm{Ba}$ & 6.54 & 7.05 & 4.2 & 7.22 & 6.95 & 7.89 & 5.26 & 5.66 \\
\hline La & 0.854 & 0.679 & 0.814 & 1.15 & 0.694 & 0.819 & 0.696 & 0.647 \\
\hline $\mathrm{Ce}$ & 1.48 & 1.3 & 1.43 & 2.1 & 1.21 & 1.38 & 1.24 & 1.07 \\
\hline $\mathrm{Pr}$ & 0.174 & 0.157 & 0.18 & 0.242 & 0.142 & 0.167 & 0.152 & 0.125 \\
\hline Nd & 0.61 & 0.549 & 0.608 & 0.876 & 0.468 & 0.567 & 0.527 & 0.46 \\
\hline Sm & 0.113 & 0.104 & 0.112 & 0.161 & 0.0849 & 0.104 & 0.0985 & 0.0843 \\
\hline $\mathrm{Eu}$ & 0.0225 & 0.0205 & 0.0215 & 0.0329 & 0.0204 & 0.0211 & 0.0205 & 0.0167 \\
\hline Gd & 0.0998 & 0.084 & 0.0908 & 0.143 & 0.0838 & 0.107 & 0.0971 & 0.0831 \\
\hline Tb & 0.0145 & 0.013 & 0.0122 & 0.0198 & 0.00932 & 0.0131 & 0.0121 & 0.011 \\
\hline Dy & 0.0819 & 0.0773 & 0.0793 & 0.125 & 0.072 & 0.0821 & 0.0817 & 0.0717 \\
\hline Ho & 0.016 & 0.0153 & 0.0155 & 0.0243 & 0.016 & 0.0151 & 0.0141 & 0.0134 \\
\hline $\mathrm{Er}$ & 0.0504 & 0.0448 & 0.0458 & 0.0755 & 0.0428 & 0.0478 & 0.0439 & 0.0421 \\
\hline $\mathrm{Tm}$ & 0.00644 & 0.00571 & 0.00643 & 0.00963 & 0.00527 & 0.00545 & 0.00526 & 0.0044 \\
\hline $\mathrm{Yb}$ & 0.0433 & 0.0397 & 0.0411 & 0.0645 & 0.0381 & 0.0471 & 0.0428 & $<\mathrm{LOQ}$ \\
\hline Lu & 0.00666 & 0.0057 & 0.00605 & 0.00941 & 0.00578 & 0.0068 & 0.00592 & 0.00513 \\
\hline $\mathrm{Hf}$ & $<\mathrm{LOQ}$ & $<\mathrm{LOQ}$ & $<\mathrm{LOQ}$ & $<\mathrm{LOQ}$ & 0.00416 & 0.00916 & $<L O Q$ & 0.006 \\
\hline $\mathrm{Pb}$ & 0.399 & 0.347 & 0.3 & 0.687 & 0.398 & 0.616 & 0.28 & 0.275 \\
\hline Th & 0.133 & 0.187 & 0.116 & 0.152 & 0.132 & 0.168 & 0.109 & 0.152 \\
\hline U & 0.0721 & 0.134 & 0.0846 & 0.0571 & 0.104 & 0.0913 & 0.096 & 0.156 \\
\hline Y/Ho & 39.3 & 37.8 & 36.7 & 33.6 & 32.3 & 39.1 & 36.7 & 37.4 \\
\hline $\mathrm{Zr} / \mathrm{Hf}$ & - & - & - & - & 48.1 & 27.1 & $<L O Q$ & 39.0 \\
\hline $\mathrm{Th} / \mathrm{U}$ & 1.8 & 1.4 & 1.4 & 2.7 & 1.3 & 1.8 & 1.1 & 1.0 \\
\hline$\sum \mathrm{REY}$ & 4.20 & 3.67 & 4.03 & 5.85 & 3.41 & 3.97 & 3.55 & 3.13 \\
\hline$\left(\mathrm{Ce}_{\mathrm{SN}} / \mathrm{Ce}^{*}{ }_{\mathrm{SN}}\right)$ & 0.868 & 0.843 & 0.787 & 0.911 & 0.828 & 0.822 & 0.825 & 0.912 \\
\hline 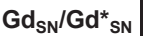 & 1.073 & 1.056 & 1.336 & 1.255 & 2.067 & 1.408 & 1.509 & 1.361 \\
\hline $\mathrm{Yb}_{\mathrm{SN}} / \mathrm{Pr}_{\mathrm{SN}}$ & 0.779 & 0.792 & 0.715 & 0.835 & 0.840 & 0.883 & 0.882 & $<L O Q$ \\
\hline $\mathrm{Eu}_{\mathrm{SN}} / \mathrm{Eu}_{\mathrm{SN}}^{*}$ & 1.051 & 1.049 & 1.064 & 1.093 & 1.329 & 1.077 & 1.114 & 1.040 \\
\hline $\mathrm{Eu}_{\mathrm{CN}} / \mathrm{Eu}^{*}{ }_{\mathrm{CN}}$ & 0.621 & 0.618 & 0.618 & 0.643 & 0.773 & 0.635 & 0.655 & 0.616 \\
\hline
\end{tabular}

subscripts: $\mathrm{SN}$ = shale-normalized, $\mathrm{CN}=$ chondrite-normalized 
TABLE 2. MAJOR \& TRACE ELEMENT CONCENTRATIONS OF FAZENDA FUNIL STROMATOLITES

\begin{tabular}{|c|c|c|c|c|c|c|c|}
\hline sample-ID & BR_FF_20a & BR_FF_20b & BR_FF_20c & BR_FF_30a & BR_FF_30b & BR_FF_30c & BR_FF_STR40a \\
\hline $\begin{array}{c}\text { type } \\
\text { digestion }\end{array}$ & $\begin{array}{c}\text { stromatolite } \\
\mathrm{HNO}_{3}\end{array}$ & $\begin{array}{c}\text { stromatolite } \\
\mathrm{HNO}_{3}\end{array}$ & $\begin{array}{c}\text { stromatolite } \\
\mathrm{HNO}_{3}\end{array}$ & $\begin{array}{c}\text { stromatolite } \\
\mathrm{HNO}_{3}\end{array}$ & $\begin{array}{c}\text { stromatolite } \\
\mathrm{HNO}_{3}\end{array}$ & $\begin{array}{c}\text { stromatolite } \\
\mathrm{HNO}_{3}\end{array}$ & $\begin{array}{c}\text { stromatolite } \\
\mathrm{HNO}_{3}\end{array}$ \\
\hline $\bar{w} w \%$ & & & & & & & \\
\hline Al2O3 & 0.22 & 0.21 & 0.21 & 0.2 & 0.19 & 0.2 & 0.21 \\
\hline $\mathrm{CaO}$ & 28.6 & 28.6 & 29.1 & 29.5 & 29.3 & 29.3 & 28.8 \\
\hline $\mathrm{FeO}$ & 0.5 & 0.6 & 0.4 & 0.6 & 0.7 & 0.7 & 0.5 \\
\hline $\mathrm{Fe} 2 \mathrm{O} 3$ & 0.6 & 0.6 & 0.5 & 0.7 & 0.8 & 0.7 & 0.5 \\
\hline MgO & 19.9 & 20.0 & 20.7 & 21.3 & 20.8 & 20.9 & 20.1 \\
\hline MnO & 0.04 & 0.05 & 0.04 & 0.05 & 0.05 & 0.05 & 0.04 \\
\hline $13 \mathrm{C}$ & -1.0 & -1.3 & -0.8 & -0.8 & -1.0 & -0.8 & -0.7 \\
\hline \pm err & 0.1 & 0.1 & 0.1 & 0.1 & 0.0 & 0.1 & 0.1 \\
\hline 180 & -3.9 & -3.5 & -3.2 & -3.2 & -3.7 & -3.6 & -3.2 \\
\hline \pm err & 0.1 & 0.1 & 0.1 & 0.1 & 0.0 & 0.1 & 0.1 \\
\hline $\mathrm{mg} / \mathrm{kg}$ & & & & & & & \\
\hline Sc & 0.724 & 0.522 & 0.448 & 0.522 & 0.388 & 0.634 & 0.84 \\
\hline $\mathrm{Ni}$ & 2.08 & 2.55 & 0.675 & 1.96 & 3.03 & 1.03 & 0.594 \\
\hline $\mathbf{R b}$ & 0.251 & 0.163 & 0.116 & 0.0868 & 0.0885 & 0.0878 & 0.122 \\
\hline $\mathrm{Sr}$ & 57.1 & 55.9 & 78.6 & 75.4 & 72.5 & 65.3 & 69.3 \\
\hline $\mathbf{Y}$ & 4.74 & 4.25 & 3.95 & 3.41 & 3.54 & 5.08 & 5.88 \\
\hline $\mathrm{Zr}$ & 0.646 & 0.498 & 0.507 & 0.686 & 0.594 & 0.664 & 0.663 \\
\hline $\mathrm{Nb}$ & 0.00811 & 0.00824 & 0.00364 & 0.00508 & 0.00555 & 0.00444 & 0.00474 \\
\hline Cs & 0.0317 & 0.0153 & 0.0141 & 0.00765 & 0.00625 & 0.00766 & 0.0134 \\
\hline $\mathrm{Ba}$ & 3.79 & 3.33 & 4.86 & 6.22 & 5.62 & 3.85 & 6.02 \\
\hline La & 1.16 & 1.22 & 0.989 & 1.09 & 0.869 & 1.15 & 1.2 \\
\hline $\mathrm{Ce}$ & 2.8 & 3.04 & 2.48 & 2.58 & 2.14 & 2.6 & 2.77 \\
\hline $\operatorname{Pr}$ & 0.406 & 0.45 & 0.327 & 0.355 & 0.317 & 0.407 & 0.45 \\
\hline Nd & 1.59 & 1.87 & 1.3 & 1.42 & 1.32 & 1.75 & 1.88 \\
\hline Sm & 0.396 & 0.447 & 0.311 & 0.332 & 0.306 & 0.403 & 0.449 \\
\hline Eu & 0.0961 & 0.111 & 0.0804 & 0.0811 & 0.0767 & 0.101 & 0.112 \\
\hline Gd & 0.478 & 0.53 & 0.383 & 0.408 & 0.397 & 0.543 & 0.573 \\
\hline Tb & 0.0785 & 0.08 & 0.0586 & 0.0607 & 0.0597 & 0.0798 & 0.0908 \\
\hline Dy & 0.542 & 0.529 & 0.435 & 0.415 & 0.401 & 0.565 & 0.623 \\
\hline Ho & 0.124 & 0.112 & 0.0949 & 0.0881 & 0.0912 & 0.123 & 0.136 \\
\hline $\mathrm{Er}$ & 0.392 & 0.334 & 0.301 & 0.29 & 0.283 & 0.415 & 0.437 \\
\hline $\mathrm{Tm}$ & 0.0515 & 0.0442 & 0.0409 & 0.0375 & 0.0381 & 0.0569 & 0.0605 \\
\hline $\mathrm{Yb}$ & 0.358 & 0.3 & 0.29 & 0.277 & $<\mathrm{LOQ}$ & 0.395 & 0.43 \\
\hline Lu & 0.0525 & 0.0457 & 0.0459 & 0.0423 & 0.0443 & 0.0651 & 0.0716 \\
\hline $\mathrm{Hf}$ & 0.0156 & 0.0116 & 0.00871 & $<\mathrm{LOQ}$ & $<\mathrm{LOQ}$ & 0.0141 & 0.0127 \\
\hline $\mathrm{Pb}$ & 1.22 & 1.03 & 0.785 & 3.01 & 1.25 & 1.93 & 1.52 \\
\hline Th & 0.416 & 0.253 & 0.236 & 0.263 & 0.218 & 0.241 & 0.367 \\
\hline U & 0.388 & 0.24 & 0.353 & 0.362 & 0.357 & 0.483 & 0.639 \\
\hline Y/Ho & 38.2 & 37.9 & 41.6 & 38.7 & 38.8 & 41.3 & 43.2 \\
\hline $\begin{array}{l}\mathrm{Zr} / \mathrm{Hf} \\
\mathrm{Th} / \mathrm{U}\end{array}$ & $\begin{array}{c}41.4 \\
1.1\end{array}$ & $\begin{array}{c}42.9 \\
1.1\end{array}$ & $\begin{array}{c}58.2 \\
0.7\end{array}$ & $\overline{-}$ & 0.6 & $\begin{array}{c}47.1 \\
0.5\end{array}$ & $\begin{array}{c}52.2 \\
0.6\end{array}$ \\
\hline$\sum$ REY & 13.3 & 13.4 & 11.1 & 10.9 & 9.9 & 13.7 & 15.2 \\
\hline $\mathrm{Ce}_{\mathrm{SN}} / \mathrm{Ce}^{*}{ }_{\mathrm{SN}}$ & 0.78 & 0.82 & 0.87 & 0.84 & 0.82 & 0.81 & 0.75 \\
\hline $\mathbf{G d}_{\mathrm{SN}} / \mathbf{G d}^{*}{ }_{\mathrm{SN}}$ & 1.18 & 1.21 & 1.41 & 1.28 & 1.24 & 1.36 & 1.21 \\
\hline $\mathrm{Yb}_{\mathrm{SN}} / \mathrm{Pr}_{\mathrm{SN}}$ & 2.76 & 2.09 & 2.78 & 2.44 & 2.73 & 3.04 & 2.99 \\
\hline $\mathrm{Eu}_{\mathrm{SN}} / \mathrm{Eu}^{*}{ }_{\mathrm{SN}}$ & 1.09 & 1.17 & 1.19 & 1.14 & 1.14 & 1.13 & 1.11 \\
\hline $\mathrm{Eu}_{\mathrm{CN}} / \mathrm{Eu}_{\mathrm{CN}}{ }$ & 0.68 & 0.72 & 0.74 & 0.70 & 0.71 & 0.70 & 0.70 \\
\hline
\end{tabular}

subscripts: $\mathrm{SN}=$ shale-normalized, $\mathrm{CN}=$ chondrite-normalized 
Table 3: Cd concentrations and $\mathrm{Cd}$ isotopic compositions of acetic acid-leachate

\begin{tabular}{|l|c|c|c|c|}
\hline name & $\mathbf{1 1 0 / 1 1 2} \mathbf{C d}$ & $\boldsymbol{\varepsilon}^{\mathbf{1 1 2 / 1 1 0}} \mathbf{C d}^{*}$ & $\mathbf{2 \sigma ^ { * * }}$ & $\mathbf{C d} \mathbf{n g} / \mathbf{g} * *$ \\
\hline BR_SG_10a & 0.5201513 & -0.58 & 0.3 & 120.1 \\
BR_SG_10c & 0.5201299 & -0.17 & 0.5 & 38.3 \\
\hline BR_FF_20b & 0.5200315 & 1.72 & 1.5 & 19.5 \\
BR_FF_30b & 0.5201595 & -0.74 & 0.7 & 17.7 \\
BR_FF_30cl & 0.5201045 & 0.32 & 0.4 & 12.1 \\
BR_FF_30cll (duplicate) & 0.5200862 & 0.67 & 0.4 & 14.9 \\
BR_FF_STR40al & 0.5202801 & -3.06 & 1.7 & 24 \\
BR_FF_STR40all (duplicate) & 0.5203041 & -3.52 & 0.5 & 20.3 \\
BR_FF_STR40b & 0.5202656 & -2.78 & 0.5 & 24.9 \\
BR_FF_STR40c & 0.5201729 & -1 & 0.3 & 16 \\
BR_FF_STR40d & 0.5201829 & -1.19 & 0.2 & 14.5 \\
BR_FF_STR50b & 0.5199411 & 3.46 & 1.8 & 5.7 \\
\hline Cambr. Stromat. Mongolia & 0.5201019 & 0.37 & 0.4 & 87.4 \\
Calcite standard (CAL-S) I & 0.5200336 & 1.68 & 1 & 322.7 \\
Calcite standard (CAL-S) II & 0.5200736 & 0.91 & 0.2 & 321 \\
\hline
\end{tabular}

*relative to NIST SRM 3108

** given in $\varepsilon^{112 / 110} \mathrm{Cd}$ units

$* * *$ obtained by isotope dilution methods

$* * * *$ calculated after Rodler et al. (2016), see supplement 


\title{
Supplemental information to Viehmann et al. 'Metal cycling in Mesoproterozoic
} microbial habitats: Insights from trace elements and stable Cd isotopes in

\author{
stromatolites'
}

\section{Petrography}

The domal stromatolites from São Gabriel and the conical stromatolites from Fazenda Funil (Fig. 2) show fundamentally different micro- and meso-structures. Stromatolites from São Gabriel show a lamination in the range of $20 \mu \mathrm{m}$ to $3 \mathrm{~mm}$. The laminae are slightly enlarged in the middle part of the stromatolitic dome and thin towards the rims (Fig. S1 A and Fig. 3 in the manuscript). The lamination is due to a variation in grain size: the finer layers consist of microspar with a grain size $<10 \mu \mathrm{m}$, the coarser layers consist of dolospar with a grain size in the $100-\mu m$-range. The whole structure is affected by pervasive recrystallization, with the micro-sparitic domains representing former micritic laminae and, presumably, the sparitic domains representing former cement. Vaguely, a botryoidal structure is observed in some of the laminae, but no sweeping extinction within precursor crystal fans is recognized under cross-polarized light. This indicates that the precursor carbonate phase, presumably aragonite, which is well known to precipitate as spherical aggregates of needle-shape crystals in modern seawater, has been entirely recrystallized. The botryoidal structure observed under the microscope thus represents a relict structure of a precursor carbonate phase that consisted of crystal fans that typically developed in the direction of stromatolite growth (Fig. S1 B). Stylolitic veins parallel to the lamination occur sporadically, indicating that the stromatolites experienced some pressure solution during burial. Sedimentary carbonate infill between individual stromatolite domes is typically composed of a micro-sparitic matrix (grain size $<10 \mu \mathrm{m}$ ), showing in parts a porphyrotopic structure. No botryoidal structure is observed in the sediment infill.

The thickness of the laminae in the conophyton-type stromatolites from the Fazenda Funil range from $20 \mu \mathrm{m}$ to $20 \mathrm{~mm}$ (Fig. S1 C). An alternation of lense-shaped laminae consisting of micro-crystalline dolomite (dolomicrite) and laminae with vertically elongated 
crystal fans is observed. The fans consist of ca. 100- $\mu \mathrm{m}$-long bladed crystals growing outward from the dolomicrite layers. Unlike the São Gabriel stromatolites, the stromatolites from Fazenda Funil show unaltered crystal structures, with fine-grained dolomicrite and crystal fans showing a sweeping extinction under cross-polarized light, indicative of a primary crystal orientation (Fig. S1 D). The crystal fans are oriented outward in the direction of stromatolite growth (inset in Fig. S1 D). Neither sulfides nor detrital clasts, such as quartz grains, clay minerals or volcanic glass fragments, were observed under the light microscope in Fazenda Funil and São Gabriel stromatolites.

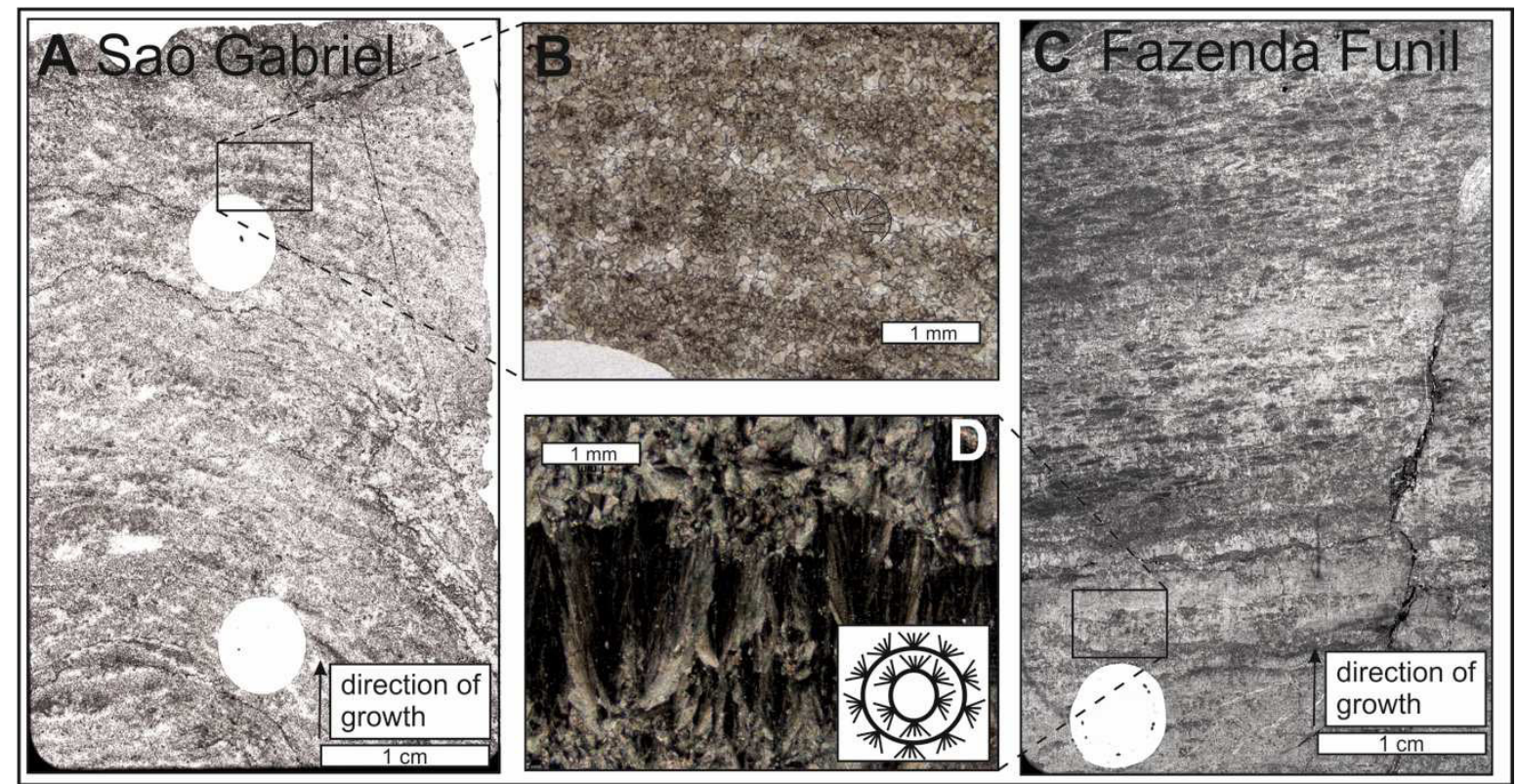

Figure S1: Low- and high-resolution thin section micrographs of the domal stromatolites from São Gabriel (A, B) and the conophyton-type stromatolites from Fazenda Funil (C, D). Botryoidal structure in the São Gabriel stromatolite is indicated in (B). The holes in panels $(A)$ and $(C)$ are the locations where material was removed by micro-drilling.

\section{Analytical methods}

\section{X-ray diffraction}

Additional samples from São Gabriel and Fazenda Funil were drilled from the existing drill holes for mineralogical analysis, using a micro-driller with a diamond-bearing drill bit. For the Fazenda Funil stromatolites, the samples were taken from individual laminae representing the two different carbonate endmembers in major/trace elements and $\mathrm{Cd}$ 
isotopes. The powdered samples were analyzed at the University of Vienna with a Panalytical X'Pert PRO diffractometer, using CuKa radiation (40 kV, $40 \mathrm{~mA})$. The samples were scanned from 3 to $70^{\circ} 2 \theta$ with a step size of $0.0167^{\circ}$ and $5 \mathrm{~s}$ per step (Fig. S2). The Xray diffraction patterns were interpreted using the Panalytical software X'Pert High score plus. Diffractograms yield exclusively dolomite peaks without any contribution of a detrital phase.

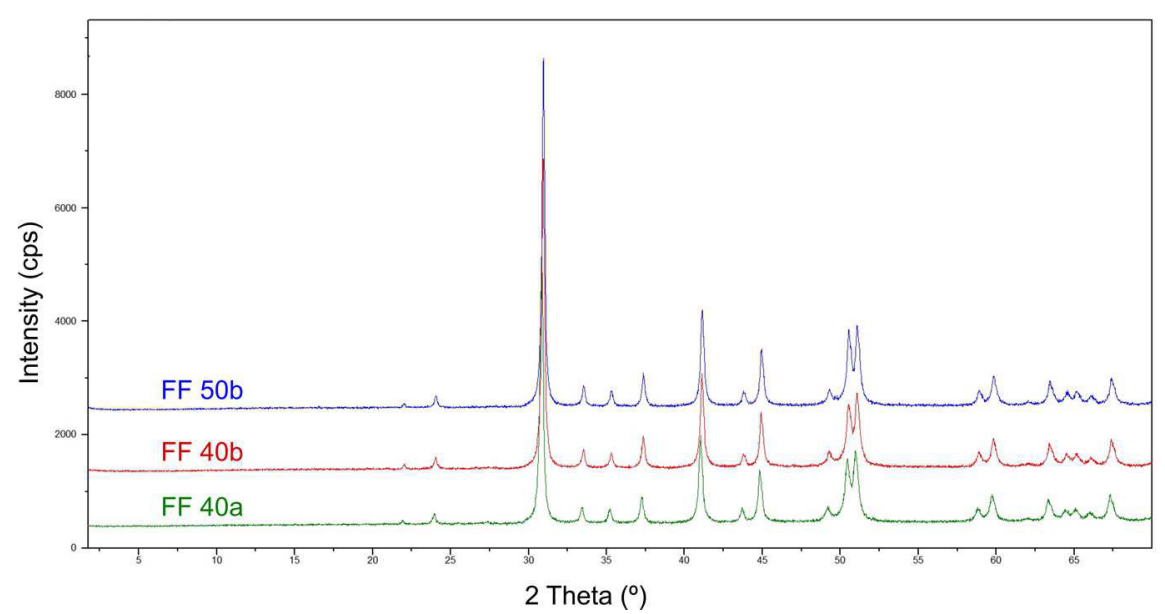

Figure S2:

$\mathrm{XRD}$ analyses of representative Fazenda Funil (top) and Sao Gabriel (BR-SG-10c; bottom) stromatolites. The two carbonates from Fazenda Funil (BR-FF$40 \mathrm{a}$, green, and BR-FF$40 \mathrm{~b}$, red) represent endmember I; BR-FF$50 \mathrm{~b}$ (blue) is endmember II. Only dolomite was detected in both carbonate endmembers from Fazenda Funil and the stromatolitic carbonate

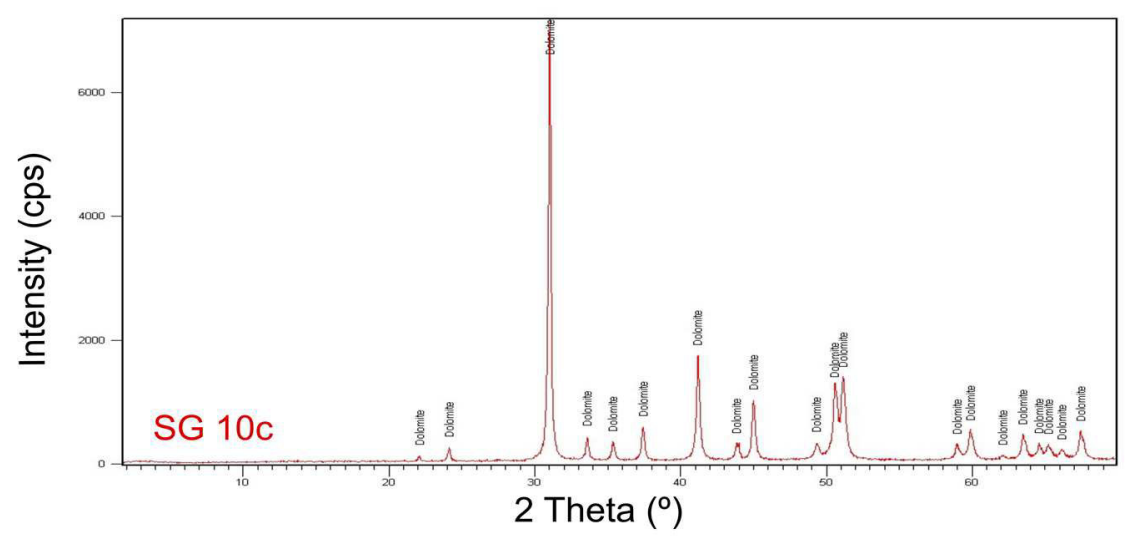
from Sao Gabriel (BRSG-10c). The narrow 104 peak at ca. $31^{\circ} 2 \theta$ indicates that the dolomite is stoichiometrically well ordered. The height ratio of the super-structural 015 peak (ca. $35.3^{\circ} 2 \theta$ ) to the 110 peak (ca. $37.3^{\circ} 2 \theta$ ) is larger than 0.5 indicating that the dolomite is also structurally well ordered (Füchtbauer and Goldschmidt, 1966).

\section{REY anomaly calculations}

REY concentrations were normalized to PAAS (Post Archean Australian Shale) after Taylor \& McLennan (1985), using the Dy concentrations of McLennan (1989; subscript SN), to C1 chondrite (after Anders \& Grevesse, 1989; subscript CN) or to the Paleoproterozoic plutonic hinterland sample EF-12B (Barbosa et al, 2008). To quantify anomalous behavior of individual REY in normalized REY patterns, the equations described in Alexander et al. 
(2008), Bau \& Dulski (2006) and Bolhar et al (2004) were used: $\mathrm{Ce} / \mathrm{Ce}^{*}=\mathrm{Ce} /(2 \mathrm{Pr}-\mathrm{Nd})$, $\mathrm{Eu} / \mathrm{Eu}^{*}=\mathrm{Eu} /(0.67 \mathrm{Sm}+0.33 \mathrm{~Tb})$ and $\mathrm{Gd} / \mathrm{Gd}^{*}=\mathrm{Gd} /(2 \mathrm{~Tb}-\mathrm{Dy})$. Due to the lack of $\mathrm{Tb}$ data of the plutonic hinterland rocks (Barbosa et al., 2008), $\mathrm{Gd} / \mathrm{Gd}^{*}$ was calculated with $\mathrm{Gd} /(0.667 \mathrm{Sm}+0.333 \mathrm{Dy})$ for normalization to hinterland patterns. Enrichment of HREY relative to LREY, and $Y$ anomalies, in normalized diagrams were quantified using $\mathrm{Yb} / \mathrm{Pr}$ ratios and $\mathrm{Y} / \mathrm{Ho}$ ratios, respectively.

\section{$C$ and $O$ isotopes}

Oxygen and carbon isotope ratios were measured using a Thermo Finnigan Gasbench II coupled with a ThermoFisher Scientific MAT-253 mass-spectrometer at the State Key Laboratory for Mineral Deposits Research at Nanjing University. Approximately $100 \mu \mathrm{g}$ of carbonate powder were reacted with $30 \mu \mathrm{l}$ of $100 \%$ phosphoric acid at $70^{\circ} \mathrm{C}$ for ca. $1.5 \mathrm{~h}$. The acid reaction transforms $\mathrm{CaCO}_{3}$ to $\mathrm{Ca}\left(\mathrm{H}_{2} \mathrm{PO}_{4}\right)_{2}, \mathrm{H}_{2} \mathrm{O}$ and $\mathrm{CO}_{2}(\mathrm{McCrea}, 1950)$. Reference gas was pure $\mathrm{CO}_{2}$ calibrated against the Vienna Pee Dee Belemnite (V-PDB) standard. We report isotope ratios in the delta notation, as per mil deviation from the V-PDB standard (Coplen, 2011). External errors of both isotope systems are smaller than $0.1 \%$ (standard deviation, 1SD), based on the reproducibility of in-house $\mathrm{CaCO}_{3}$ carbonate reference material (GBW04405). A phosphoric acid-dolomite fractionation factor at $70^{\circ} \mathrm{C}$ of 1.01066 was used for $\delta^{18} \mathrm{O}_{\mathrm{dol}}$ calculation, deriving from linear regression of experiments at 25 , 50 and $100^{\circ} \mathrm{C}$ (Rosenbaum and Sheppard, 1986; Ghosh et al., 2005).

\section{Cd isotopes}

Cadmium isotope compositions were measured in $\mathrm{pH} 5.5$ buffered $1 \mathrm{~N}$ acetic acid leachates. All $\mathrm{Cd}$ isotope ratios are reported relative to the reference material NIST SRM 3108 (Abouchami et al., 2012). The formula for the relative deviation of the value of the sample from the value of the reference material $(\mathrm{RM})$ is given as:

SE1 $\quad \varepsilon^{112 / 110} C d=\left[\frac{{ }^{110} C d /{ }^{112} C d_{R M}}{{ }^{110} C d /{ }^{112} C d_{\text {Sample }}}-1\right] \times 10^{4}$ 
The analyzed $\mathrm{Cd}$ isotope compositions and $\mathrm{Cd}$ concentrations were corrected for detrital Cd contamination. We used the approach by Rodler et al. (2016) to estimate the fraction of detrital $\mathrm{Cd}$ in the analyzed carbonate leachates and to correct the measured isotopic compositions for that effect. We assume that modern loess is the currently best available representative for the concentration and isotopic composition of detrital contamination from eroded upper continental crust. The average Cd isotope composition $\left(+0.04 \varepsilon^{112 / 110} C d\right.$ relative to NIST SRM 3108) and the average Cd concentration (121 ppb) of loess are reported in Schmidt et al. (2009b), and the Al concentration for loess (84000 ppm; sample LT-DJ-L1-5) is provided in Park et al. (2012). To calculate the authigenic Cd concentrations in our samples ( $\left.\mathrm{Cd}_{\text {auth. }}\right)$ we subtracted the calculated detrital $\mathrm{Cd}$ fraction $\left(\mathrm{Cd}_{\text {det. }}\right)$ from the measured $\mathrm{Cd}$ concentrations, where $\mathrm{Cd}_{\text {det. }}$ was calculated from $\mathrm{C} \mathrm{d}_{\text {loess }}$ assuming that it is proportional to Al concentrations:

SE2 $C d_{\text {auth. }}=C d_{\text {sample }}-\left(C d_{\text {loess }} \cdot\left(A l_{\text {sample }} / A l_{\text {loess }}\right)\right)$

With this we are able to calculate the fraction of detrital $\mathrm{Cd}$ in $\%$ :

SE3 $C d_{\text {det. }}(\%)=\frac{\left(C d-C d_{\text {auth. }}\right)}{\left(C d_{\text {auth. }} / 100\right)}$

SE4 $F=\mathrm{Cd}_{\text {det. }} / 100$

Finally, the $F$ value (i.e. the fraction of detrital $\mathrm{Cd}$ contribution where 1 means that $\mathrm{Cd}$ is entirely detrital, and 0 means that $\mathrm{Cd}$ is entirely authigenic) can be used to correct the measured $\mathrm{Cd}$ isotope compositions for the impact of detrital material:

SE5 $\quad \varepsilon^{112 / 110} C d_{\text {auth. }}=\frac{\left(\varepsilon^{112 / 110} C d *\left(F * C d_{\text {det. }}+(1-F) * C d_{\text {auth }}\right)-\left(C d^{112 / 110} C d_{\text {loess }} * C d_{\text {det. }} * F\right)\right)}{\left(C d_{\text {auth. }}(1-F)\right)}$

The calculated $\mathrm{Cd}_{\text {det. }}$ fractions $(F)$ range from 1.2 to $11.8 \%$ in the Fazenda Funil samples, except for one sample with a $\mathrm{Cd}_{\mathrm{det}}$ of $24.8 \%$ (Table 3). The detritus-corrected Cdauth. concentrations and isotopic compositions are listed in Table 3. The maximum offset between the measured and the calculated Cd isotope compositions is $0.34 \varepsilon^{112 / 110} C d$ units. The plot of detritus-corrected and uncorrected $\varepsilon^{112 / 110} C d$ values vs. Cd concentrations (Fig. S3) clearly demonstrates that the detritus-correction only has a minor impact on the overall 
Cd budget of the studied stromatolites. It further shows that the co-variation between $\varepsilon^{112 / 110} \mathrm{Cd}$ and $\mathrm{Cd}$ concentrations observed in the detritus-corrected and uncorrected data shows an very similar Rayleigh fractionation factor $\alpha$. Because we have to compare the Al concentrations in $5 \mathrm{~N} \mathrm{HNO}_{3}$ leached samples with the $\mathrm{Cd}$ concentrations and isotopic compositions obtained in acetic acid leachates for the detritus correction, the corrected $C d_{\text {auth }}$ concentrations and isotopic compositions represent maximum values. The actual effect of detrital contamination on the $\mathrm{Cd}$ budget is probably much smaller.

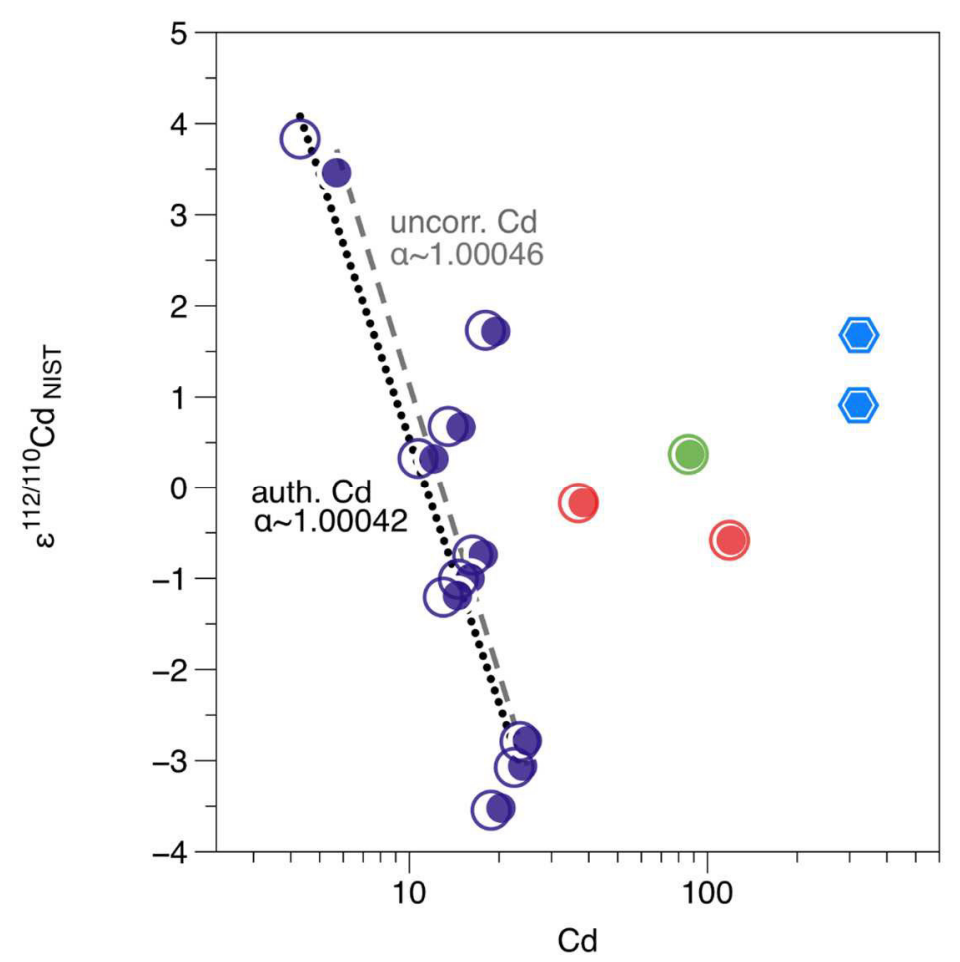

Figure S3: Co-variation of measured (closed circles) and detrituscorrected (open circles) $\varepsilon^{112 / 110} \mathrm{Cd}$ and $\mathrm{Cd}$ concentrations in carbonate leachates of the Paranoá Group stromatolites. The measured stromatolitic Cd concentrations differ in the range of $1.2 \%$ to $11.8 \%$ (24.8\% in the sample with the lowest $\mathrm{Cd}$ concentration) from the pure authigenic carbonate, whereby they show the highest disparity at lowest $\mathrm{Cd}$ concentrations. The maximum variation in $\varepsilon^{112 / 110} \mathrm{Cd}$ is below 0.37 epsilon units. However, the overall co-variation between uncorrected and detritus-corrected values in this plot is identical, indicating that detrital contamination has an insignificant impact on the $\mathrm{Cd}$ budget of the stromatolitic carbonates analyzed here.

121 The $\mathrm{Cd}$ concentrations in acetic acid leachates of the Fazenda Funil conophyta correlate 122 negatively with the $\varepsilon^{112 / 110} C d$ values $\left(R^{2}=0.85\right.$, Fig. 5). Following the findings of Abouchami 123 et al. (2011) describing the nutrient cycle of the Southern Ocean, an inverse correlation of 124 dissolved $\mathrm{Cd}$ concentrations and isotopic compositions can be best described by Rayleigh 125 fractionation. In such a model, light $\mathrm{Cd}$ isotopes fractionate into organic matter during primary 126 production, leaving the remaining ambient fluid depleted in light $\mathrm{Cd}$. Kinetic fractionation due 127 to the enzymatic pathway of Cd uptake, results in an enrichment of heavy Cd isotopes in the 128 ambient fluid. Authigenic carbonates precipitating from surface water would therefore be 129 enriched in heavy $\mathrm{Cd}$. 

expected to show a linear trend with increasing $\mathrm{Cd}$ concentrations if plotted on a logarithmic scale. This would be consistent with a Rayleigh distillation (Abouchami et al., 2011, 2014; Ripperger et al., 2007). The fractionation factor $\alpha$ between the fluid and the instantaneously precipitated carbonate can be obtained from the slope of the linear relation between $\varepsilon^{112 / 110} C d$ and $C d$ concentrations $(\operatorname{In}(\mathrm{Cd}))$. In the Fazenda Funil stromatolites $\varepsilon^{112 / 110} C d$ and Cd concentrations vary over a range of $6 \varepsilon^{112 / 110} C d$ units from -3.52 to +3.46 and 5.7 and $24.9 \mathrm{ng} / \mathrm{g}$, respectively, resulting in an $\alpha$ of 1.00046 as calculated by the Rayleigh equation:

SE6 $\quad \frac{R}{R_{0}}=\left(\frac{c}{c_{0}}\right)^{\frac{1}{\alpha}-1}$

Following the Rayleigh distillation model, the relationship between the isotopic composition and the fraction of $\mathrm{Cd}$ remaining in the fluid $f$ can be expressed as

SE7 $\quad \varepsilon_{\text {carb }} \approx \varepsilon_{0}+\left(\frac{1}{\alpha}-1\right) \times \ln (f)$

where $\varepsilon_{c a r b}$ is the Cd isotope composition of instantaneously precipitated carbonate, $\varepsilon_{0}$ is the starting isotopic composition of the oxic fluid endmember and $f$ is the remaining fraction of $\mathrm{Cd}$ in the ambient fluid that can react. Because we do not know the Cd isotope composition and Cd concentration in Mesoproterozoic seawater we assume that the endmember that (1) shows the highest $\mathrm{Cd}$ and $\mathrm{U}$ concentrations, (2) has the most negative $\mathrm{Ce}_{\mathrm{SN}}$ anomaly, and (3) is most depleted in $\mathrm{Mn}$ represents the precipitate from unaltered seawater. The samples BR_FF_STR40a I and II show some of the highest Cd concentrations of 20.3 and $24 \mathrm{ng} / \mathrm{g}$, respectively, while having the lowest $\varepsilon^{112 / 110} C d$ values (as low as -3.52). These samples represent our carbonate endmember I (see text, Table 3). In order to define the fraction of Cd adsorbed from seawater onto organic matter, precipitated as Cd-sulfide, or partitioned into carbonate minerals we define the fraction $f$ as $\mathrm{N} / \mathrm{N}_{0}$, where $\mathrm{N}$ is the concentration of $\mathrm{Cd}$ in

153 the carbonate and $\mathrm{N}_{0}$ is the concentration of $\mathrm{Cd}$ in the ancient fluid (seawater or pore-water). 
155 to kinetic isotope effects that are insensitive to fluid temperature or $\mathrm{Mg}^{2+}$ content under 156 invariant salinity conditions. We assume that the highest $\mathrm{Cd}$ concentration $(24 \mathrm{ng} / \mathrm{g}$ in 157 endmember I) is close to the concentration in a carbonate that would have formed at the beginning of a Rayleigh distillation. In order to fit the Rayleigh distillation curve to the measured Cd data (Fig. 5b), we set the Cd concentration for $\mathrm{N}_{0}$ to $27 \mathrm{ng} / \mathrm{g}$, i.e., close to the highest measured concentration in our sample suite.

The offset of the isotopic compositions of the instantaneous carbonate precipitate and the ambient fluid can be approximately defined as $\Delta \varepsilon^{112 / 110} C d_{\text {fluid-carb. }}=1-1 / \alpha * 10000$ (given in $\varepsilon$ units). According to the experimental research done by Horner et al. (2011) the Cd isotope composition of instantaneously precipitated calcite would have been up to $2.27 \varepsilon$ units higher than the $\mathrm{Cd}$ isotope composition of the ambient fluid (depending on the salinity of the fluid). Applying this maximum isotopic offset to our endmember I (see text) results in a value of $\sim-1.25 \varepsilon^{112 / 110} C d_{\text {fluid }}$ that is significantly lower than values reported for the modern deep ocean (+1.17; Ripperger et al., 2007) and the average loess value $(+0.04)$ reported by Schmitt et al. (2009) that we apply as the best value currently available from the literature for average upper crust. The composition of a fluid from which carbonate forms within the microbial mat (endmember II) would therefore have been around $5.7 \varepsilon^{112 / 110} C d$ units at an $f$ of 0.21 . In consequence, a small fraction of increasingly heavier $\mathrm{Cd}$ isotopes can still react and may have been incorporated into carbonates forming within the microbial mat.

Assuming that the carbonate minerals within the microbial environment formed instantaneously, and no later diagenetic (i.e. metamorphous) isotopic exchange happened between carbonate minerals and organic matter or diagentic/meteoric pore-waters (see discussion in 5.1 and 5.2), all analyzed $\varepsilon^{112 / 110} C d_{\text {dol }}$ values vs. concentrations will plot on a Rayleigh curve (Fig. 5b). The equation for this curve is given below:

SE8 $\varepsilon_{\Sigma}=\left(10000+\varepsilon_{0}\right) \times\left(\left(1-f^{\alpha}\right) /(1-f)\right)-10000$ 


\section{References}

Abouchami, W., Galer, S. J. G., de Baar, H. J. W., Middag, R., Vance, D., Zhao, Y., et al. (2014). Biogeochemical cycling of cadmium isotopes in the Southern Ocean along the Zero Meridian. Geochimica Et Cosmochimica Acta, 127(C), 348-367. http://doi.org/10.1016/j.gca.2013.10.022

Abouchami, W., Galer, S. J. G., Horner, T. J., Rehkämper, M., Wombacher, F., Xue, Z Z., et al. (2012). A Common Reference Material for Cadmium Isotope Studies - NIST SRM 3108. Geostandards and Geoanalytical Research, 37(1), 5-17. http://doi.org/10.1111/j.1751-908X.2012.00175.x

Abouchami, W., Galer, S. J. G., de Baar, H. J. W., Alderkamp, A. C., Middag, R., Laan, P., et al. (2011). Modulation of the Southern Ocean cadmium isotope signature by ocean circulation and primary productivity. Earth and Planetary Science Letters, 305(1-2), 83-91. http://doi.org/10.1016/j.epsl.2011.02.044

Alexander, B. W., Bau, M., Andersson, P., \& Dulski, P. (2008). Continentally-derived solutes in shallow Archean seawater: Rare earth element and Nd isotope evidence in iron formation from the $2.9 \mathrm{Ga}$ Pongola Supergroup, South Africa. Geochimica et Cosmochimica Acta, 72(2), 378-394. https://doi.org/10.1016/j.gca.2007.10.028

Barbosa, J. F. S., Peucat, J. J., Martin, H., da Silva, F. A., de Moraes, A. M., Corrêa-Gomes, L. C., ... Fanning, C. M., 2008. Petrogenesis of the late-orogenic Bravo granite and surrounding high-grade country rocks in the Palaeoproterozoic orogen of ItabunaSalvador-Curaçá block, Bahia, Brazil. Precambrian Research, 167(1-2), 35-52. https://doi.org/10.1016/j.precamres.2008.06.002

Bau, M., \& Dulski, P. (1996). Distribution of yttrium and rare-earth elements in the Penge and Kuruman iron-formations, Transvaal Supergroup, South Africa. Precambrian Research, 79(79), 37-55. https://doi.org/10.1016/0301-9268(95)00087-9

Bolhar, R., Kamber, B. S., Moorbath, S., Fedo, C. M., \& Whitehouse, M. J. (2004). Characterisation of early Archaean chemical sediments by trace element signatures. Earth and Planetary Science Letters, 222(1), 43-60. https://doi.org/10.1016/j.epsl.2004.02.016

Coplen, T. B. (2011). Guidelines and recommended terms for expression of stable-isotoperatio and gas-ratio measurement results. Rapid Communications in Mass Spectrometry. http://doi.org/10.1002/rcm.5129

Füchtbauer, H. and Goldschmidt, H. (1966) Beziehungen zwischen Calzium-Gehalt und Bildungsbedingungen der Dolomite. Geologische Rundschau, 55, 29-40.

Ghosh, P., Patecki, M., Rothe, M., \& Brand, W. A. (2005). Calcite-CO2 mixed into CO2-free air: a new CO2-in-air stable isotope reference material for the VPDB scale. Rapid Communications in Mass Spectrometry, 19(8), 1097-1119. http://doi.org/10.1002/rcm.1886

Horner, T. J., Rickaby, R. E. M., \& Henderson, G. M. (2011). Isotopic fractionation of cadmium into calcite. Earth and Planetary Science Letters, 312(1-2), 243-253. http://doi.org/10.1016/j.epsl.2011.10.004

McCrea, J. M. (1950). On the Isotopic Chemistry of Carbonates and a Paleo- 
Taylor, S.R., McLennan, S.M., 1985. The Continental Crust: Its Composition and Evolution. Blackwell, Oxford, p. 312. 